

\section{DISCLAIMER}

This report was prepared as an account of work sponsored by an agency of the United States Government. Neither the United States Govemment nor any agency thereof, nor any of their employees, makes any warranty, express or implied, or assumes any legal liability or responsibility for the accuracy, completeness, or usefulness of any information, apparatus, product or process disclosed, or represents that its use would not infringe privalely owned rights. References herein to any specific commercial product, process, or service by trade name, trademark, manufacturer. or otherwise. does not necessarily constitute or imply its endorsement. recommendation. or favoring by the United States Government or any agency thereof. The views and opinions of authors expressed herein do not necessarily state or reflect those of the United States Government or any agency thereot. 


\title{
In Situ Encapsulation Bench-Scale Demonstration Report FY-94 (for TTP-ID 14:2012)
}

\author{
Jerry R. Weidner \\ Peter G. Shaw
}

Published January 1995

\section{Idaho National Engineering Laboratory Lockheed Idaho Technologies Company Idaho Falls, Idaho 83415}

Prepared for the

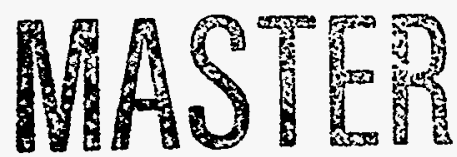

U.S. Department of Energy

Assistant Secretary of Environmental Management

Under DOE Idaho Operations Office

Contract DE-AC07-94ID13223 


\section{DISCLAIMER}

Portions of this document may be illegible in electronic image products. Images are produced from the best available original document. 
In Situ Encapsulation Bench-Scale Demonstration Report FY-94 (for TTP-ID 142012)

INEL-95/0039

Prepared by
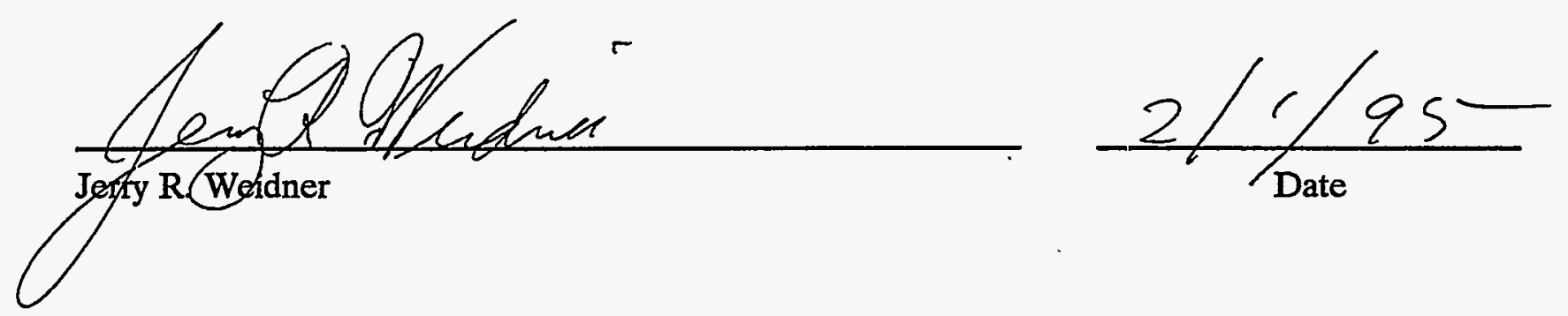

Reviewed by
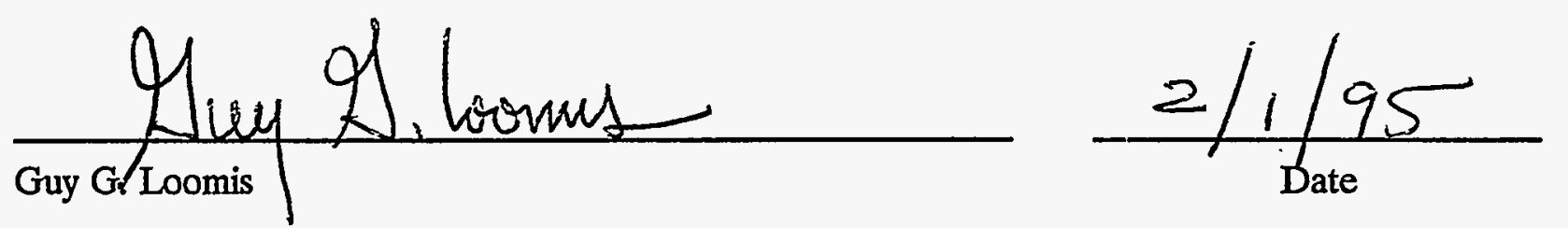

Approved by

Robert F. Heard

$$
\frac{2 / 2 / 95}{\text { Date }}
$$




\begin{abstract}
This report describes the test objectives, procedures, and results of the laboratory-scale tests of in situ waste encapsulation of buried waste using a synthetic analogue of natural cement. The products of the reaction $\mathrm{FeSO}_{4} \cdot 7 \mathrm{H}_{2} \mathrm{O}+\mathrm{Ca}(\mathrm{OH})_{2}=$ gypsum and iron oxide/hydroxide were examined as a possible waste encapsulation material for application at the Subsurface Disposal Area at the Idaho National Engineering Laboratory. This technique for transuranic waste encapsulation is being pursued by the Buried Waste Integrated Demonstration as a possible candidate containment and stabilization method for geologic time. The data indicate that the iron waste encapsulation materials tested are appropriate choices for the intended purpose. Based on these observations and conclusions, full-scale tests are recommended to determine the performance of the iron waste isolation materials under field conditions and for extended time periods. The viscosity of the reagents indicates that jet grouting is probably an appropriate application method.
\end{abstract}




\section{EXECUTIVE SUMMARY}

This report describes the test objectives, procedures, and results of the laboratory-scale tests of in situ waste encapsulation of buried waste using a synthetic analogue of natural cement. Specifically, the products of the reaction $\mathrm{FeSO}_{4} \cdot 7 \mathrm{H}_{2} \mathrm{O}+\mathrm{Ca}(\mathrm{OH})_{2}=$ gypsum and iron oxide/hydroxide were examined as a possible waste encapsulation material for application at the Subsurface Disposal Area (SDA) at the Idaho National Engineering Laboratory (INEL). This technique for transuranic waste encapsulation is being pursued by the Buried Waste Integrated Demonstration as a possible candidate containment and stabilization method for geologic time.

The properties of the waste isolation material established by the test program include (a) effect of encapsulation treatment on hydraulic conductivity of INEL soil; (b) compressive strength of treated INEL soil and the waste encapsulation material; (c) mineralogy and microstructure of the waste encapsulation material; (d) compatibility of waste encapsulation material with possible waste materials to include nitrates, machine cutting oil, and metallic iron; (e) leachability of hazardous metals encapsulated by the waste isolation material; (f) solution $\mathrm{pH}$;

(g) time for reaction initiation; and (h) viscosity values of reagent slurries.

The data indicate that the iron waste encapsulation materials tested are appropriate choices for the intended purpose, namely a material that when mixed with INEL soil

- Has hydraulic conductivity value less than $10^{-6} \mathrm{~cm} / \mathrm{s}$

- Has compressive strength greater than the Nuclear Regulatory Commission 50 psi minimum, which is sufficient to prevent collapse of the void space in waste

- Removes hazardous metals, with the exception of cadmium, from solution by adsorption or other mechanism

- Appears to be chemically and physically inert with respect to the bulk of the waste materials likely to be found at the SDA, particularly metallic iron, machine cutting oil, and nitrate salts.

Based on these observations and conclusions, full-scale tests are recommended to determine the performance of the iron waste isolation materials under field conditions and for extended time periods (e.g., five years).

The viscosity of the reagents indicates that jet grouting is probably an appropriate application method. The initial reaction speed and heat generated indicate that the reagent slurries will probably be required to be pumped separately and mixed during injection if jet grouting is the application method. 



\section{CONTENTS}

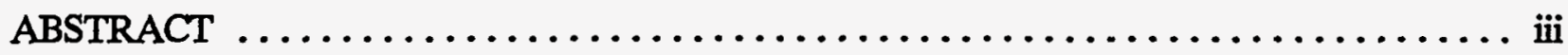

EXECUTIVE SUMMARY $\ldots \ldots \ldots \ldots \ldots \ldots \ldots \ldots \ldots \ldots \ldots \ldots \ldots \ldots \ldots \ldots \ldots$

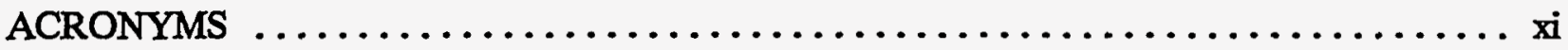

1. TECHNOLOGY DESCRIPTION $\ldots \ldots \ldots \ldots \ldots \ldots \ldots \ldots \ldots \ldots \ldots \ldots \ldots$

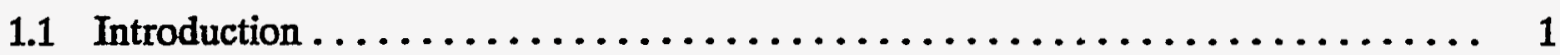

1.1.1 Background $\ldots \ldots \ldots \ldots \ldots \ldots \ldots \ldots \ldots \ldots \ldots \ldots \ldots \ldots, 2$

1.1.2 Past INEL and DOE In Situ Waste Encapsulation Demonstrations ...... 3

1.1.3 Nature of Test $\ldots \ldots \ldots \ldots \ldots \ldots \ldots \ldots \ldots \ldots \ldots, 3$

1.2 Technology Need $\ldots \ldots \ldots \ldots \ldots \ldots \ldots \ldots \ldots \ldots \ldots \ldots \ldots \ldots, 5$

2. TEST OBJECTIVES $\ldots \ldots \ldots \ldots \ldots \ldots \ldots \ldots \ldots \ldots \ldots \ldots \ldots \ldots \ldots \ldots \ldots$

2.1 Data Quality Objectives $\ldots \ldots \ldots \ldots \ldots \ldots \ldots \ldots \ldots \ldots \ldots \ldots \ldots$

3. EXPERIMENTAL DESIGN AND PROCEDURES $\ldots \ldots \ldots \ldots \ldots \ldots \ldots \ldots, 8$

3.1 Reagent Characterization $\ldots \ldots \ldots \ldots \ldots \ldots \ldots \ldots \ldots \ldots \ldots \ldots, 8$

3.2 Hydraulic Conductivity Measurements $\ldots \ldots \ldots \ldots \ldots \ldots \ldots \ldots \ldots, 9$

3.3 Waste Compatibility Tests and Compressive Strength Tests $\ldots \ldots \ldots \ldots \ldots \ldots$

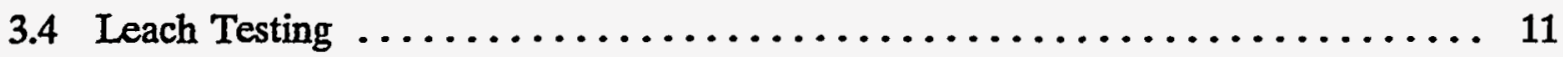

3.5 Field Application Parameters $\ldots \ldots \ldots \ldots \ldots \ldots \ldots \ldots \ldots \ldots \ldots \ldots \ldots$

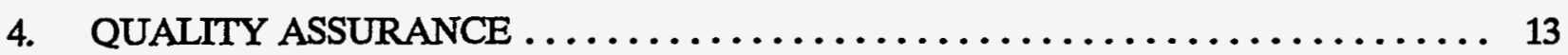

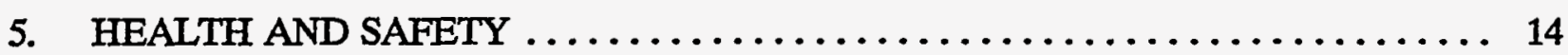

6. ENVIRONMENTAL OVERVIEW $\ldots \ldots \ldots \ldots \ldots \ldots \ldots \ldots \ldots \ldots \ldots \ldots \ldots \ldots$

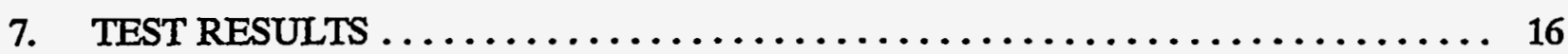

7.1 Waste Compatibility and Compressive Strength $\ldots \ldots \ldots \ldots \ldots \ldots \ldots \ldots$

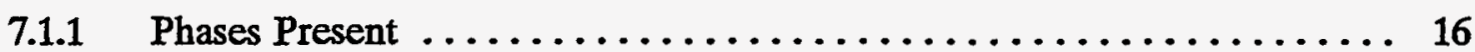

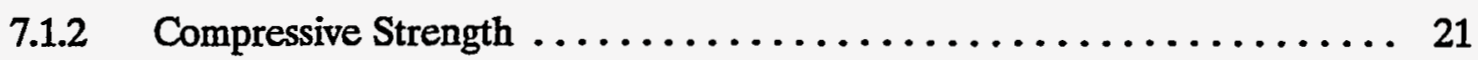




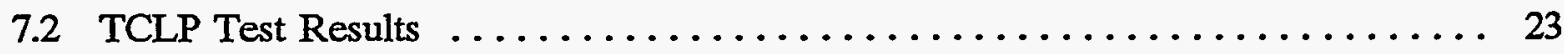

7.3 Results of the Hydraulic Conductivity Measurements . . . . . . . . . . 24

7.4 Field Application Parameters $\ldots \ldots \ldots \ldots \ldots \ldots \ldots \ldots \ldots \ldots \ldots \ldots \ldots \ldots \ldots \ldots \ldots$

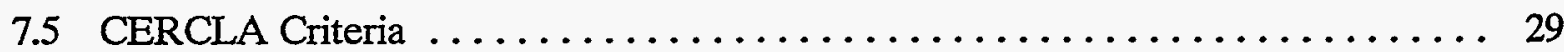

8. OUTPUT/PRODUCTS $\ldots \ldots \ldots \ldots \ldots \ldots \ldots \ldots \ldots \ldots \ldots \ldots \ldots \ldots \ldots \ldots \ldots$

9. PROBLEMS AND ISSUES FROM THE TESTING $\ldots \ldots \ldots \ldots \ldots \ldots \ldots \ldots$

10. FULL_SCALE IMPLEMENTATION $\ldots \ldots \ldots \ldots \ldots \ldots \ldots \ldots \ldots \ldots \ldots$

11. CONCLUSIONS AND RECOMMENDATIONS $\ldots \ldots \ldots \ldots \ldots \ldots \ldots \ldots \ldots$

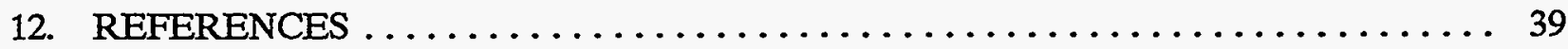

Appendix A-X-ray Powder Diffraction and Scanning Electron

Microscope Procedures $\ldots \ldots \ldots \ldots \ldots \ldots \ldots \ldots \ldots \ldots \ldots \ldots \ldots \ldots \ldots \ldots \ldots$

Appendix B-X-ray Fluorescence Analysis Procedures $\ldots \ldots \ldots \ldots \ldots \ldots \ldots \ldots \ldots \ldots$

Appendix C-Permeability Measurement Procedure and Test Conditions $\ldots \ldots \ldots \ldots \ldots \ldots$-1

FIGURES

1. Photomicrographs of iron encapsulation material, sample 9 V1-NA. . . . . . . . 19

2. Photomicrographs of encapsulation material (soil mixture), sample 2 V1-NAS. . . . . . 20

3. Hydraulic conductivity versus time for each test specimen $\ldots \ldots \ldots \ldots \ldots \ldots \ldots$

4. Titration of iron sulfate $\left(\mathrm{FeSO}_{4}\right)$ with calcium hydroxide $\left[\mathrm{Ca}(\mathrm{OH})_{2} \ldots \ldots \ldots . \ldots 27\right.$

5. Titration of agricultural grade iron sulfate $\left(\mathrm{FeSO}_{4}\right)$ with calcium

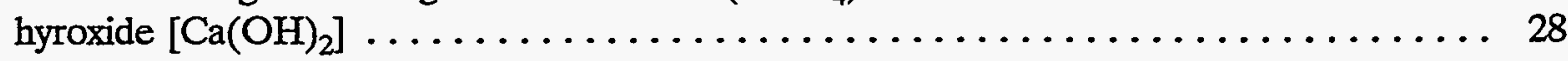

6. Reaction of iron sulfate $\left(\mathrm{FeSO}_{4}\right)$, calcium hydroxide $\left[\mathrm{Ca}(\mathrm{OH})_{2}\right]$, and soil at room

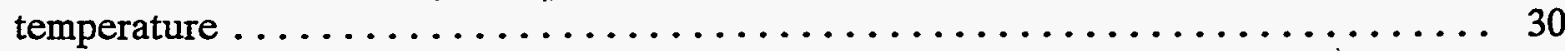

7. Iron sulfate $\left(\mathrm{FeSO}_{4}\right)$ and calcium hydroxide $\left[\mathrm{Ca}(\mathrm{OH})_{2}\right]$ reaction at reduced

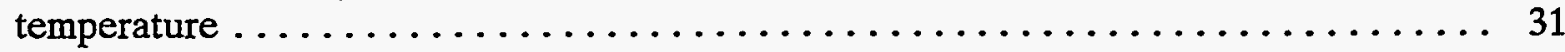

8. Calcium hydroxide (agricultural lime) $\left[\mathrm{Ca}(\mathrm{OH})_{2}\right]$ slurry viscosity $\ldots \ldots \ldots \ldots \ldots \ldots$

9. Agricultural grade iron sulfate $\left(\mathrm{FeSO}_{4}\right)$ solution viscosity $\ldots \ldots \ldots \ldots \ldots \ldots \ldots$ 


\section{TABLES}

1. Sample mineralogy after treatment. ........................ 17

2. Relation between compressive strength and soil-waste isolation material

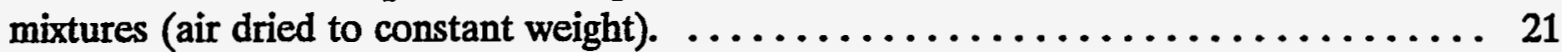

3. Compressive strength of treated soils containing metallic iron (air dried

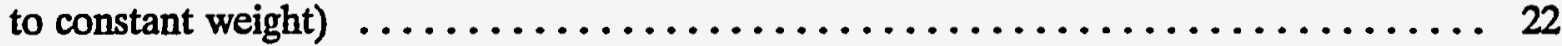

4. Compressive strength of treated soils containing potassium nitrate (air dried to constant weight)

5. Compressive strength of treated soils containing Texas Regal Oil (air dried to constant weight)

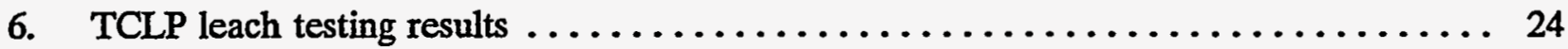

7. Hydraulic conductivity results-final hydraulic conductivity and total effluent during test 


\section{ACRONYMS}

ASTM American Society of Testing and Materials

CERCLA Comprehensive Environmental Response, Compensation, and Liability Act

CFA Central Facility Area

DOE Department of Energy

EPA Environmental Protection Agency

INEL Idaho National Engineering Laboratory

IRC Idaho Research Center

NRC Nuclear Regulatory Commission

ppm part per million

$\mathrm{pH} \quad$ negative logarithm of hydrogen concentration

RWMC Radioactive Waste Management Complex

SDA Subsurface Disposal Area

SEM scanning electron microscope

SOW statement of work

TCLP toxic characteristics leaching procedure

WAG Waste Area Group

XRD $\quad$ x-ray powder diffraction

XRF $\quad$ x-ray fluorescence 


\section{In Situ Encapsulation Bench-Scale Demonstration Report FY-94 (for TTP-ID 142012)}

\section{TECHNOLOGY DESCRIPTICN}

\subsection{Introduction}

This report describes the results of a set of laboratory proof-of-principle and engineering design activities necessary to determine if (a) synthetic analogues of natural cements, specifically iron oxide(s) and gypsum, can be used to isolate buried transuranic waste from the natural environment and (b) a field demonstration of this concept can be carried out in FY-95.

The concept is based on the principle that the ideal waste isolation materials are synthetic analogues of those natural encapsulating materials (cements) that are in equilibrium with the natural environment in which they occur. If equilibrium is achieved, then such materials will remain intact as long as the natural environment is not significantly altered or changed. Some examples of the common natural cements in sedimentary rocks are dated at $>1.5$ billion years. Long term encapsulation is mandatory for contaminants such as plutonium ( 24,000 year half-life) in the buried transuranic waste.

There are several natural materials that effectively isolate particulate objects from their surrounding environment and that would also be inexpensive and safe to apply if used for encapsulating buried waste. These are the low-temperature, natural processes and materials that produce sedimentary rocks. Loose, unconsolidated soil or sediment is converted into a hard, durable, impermeable rock by the precipitation of minerals (cement) such as calcite (calcium carbonate, $\left.\mathrm{CaCO}_{3}\right)$ or hematite $\left(\mathrm{Fe}_{2} \mathrm{O}_{3}\right)$ between the particles of unconsolidated material. Caliche (soil cemented by calcite and also gypsum), sandstone, and other sedimentary rocks are formed in this manner. The most common natural cements are $\mathrm{CaCO}_{3}$, and $\mathrm{Fe}_{2} \mathrm{O}_{3}$, together with other iron oxides and oxyhydroxides, and various forms of silica $\left(\mathrm{SiO}_{2}\right)$. Less common cements include gypsum $\left(\mathrm{CaSO}_{4} \cdot 2 \mathrm{H}_{2} \mathrm{O}\right)$.

For application at the Idaho National Engineering Laboratory (INEL), the iron oxides, including $\mathrm{Fe}_{2} \mathrm{O}_{3}$, goethite $[\mathrm{FeO}(\mathrm{OH})]$, ferri-ferrous iron oxides, and oxyhydroxides, are proposed as primary waste encapsulation materials because these minerals are forming by natural processes in the desert soils adjacent to the INEL Subsurface Disposal Area (SDA) waste sites. The presence of iron oxides and the observation that they are forming at present indicates that they are virtually in equilibrium with the INEL environment and would be expected to last indefinitely as a waste encapsulation material. The presence of natural iron oxide minerals indicates that the soil waters are saturated with iron and are incapable of dissolving additional iron.

An additional benefit of the iron oxide materials is their potential to act as a chemical barrier as well as a physical barrier. Most of the iron oxides are known for their ability to adsorb metal ions from solution. Morrison and Spangler ${ }^{1}$ have shown that it can effectively remove uranium and molybdenum from groundwater and suggest it as a possible chemical barrier to 
isolate buried waste. Application at the SDA potentially provides an additional barrier to the migration of heavy metal and transuranic ions.

\subsubsection{Background}

Technical interest in the use of synthetic analogues of natural cements as waste encapsulation materials arose from the search for a less expensive alternative to the remove-andtreat solution to the problem of buried waste at the INEL and other government and industrial facilities. At the INEL, 2 million $\mathrm{ft}^{3}$ of waste have been buried in pits and trenches and are commingled with 6-8 million $\mathrm{ft}^{3}$ of soil. Similar amounts of buried waste exist at other Department of Energy (DOE) sites. The complexity and expense of the remove-and-treat solution to the buried waste problem is clearly enormous and has potential health related risks. An alternative approach is to treat the waste in place using such methods as in situ vitrification, electrokinetic, or other treatment technology as appropriate. ${ }^{2}$ Each of these methods has certain advantages and disadvantages and are useful for the solution of certain problems. None are approved for the remediation of buried waste at the INEL. An obvious and simple alternative solution to the buried waste problem is to simply leave the waste in place, an approach that also has obvious disadvantages. If the waste is left in place, the potential exists for some contamination of the natural environment due to migration through water intrusion. Subsidence of the waste site due to waste container deterioration enhances the intrusion. These problems can be eliminated if the buried waste can be effectively encapsulated and permanently isolated from the environment by some mechanism.

The successful development and application of these techniques would produce a permanent (in terms of geologic time) in situ encapsulation and isolation of the waste materials from the environment. The process would also fill the void space in the waste with rock-like material and permanently eliminate the possibility of collapse or slumping of the waste site. The processes would be far less expensive and much safer than any of the ex situ waste treatment systems when applied to the remediation of buried waste. They provide the additional option of future retrieval, if this is desired.

Waste isolation techniques function by preventing the migration of waste components from the waste site. This is accomplished by (a) a physical barrier that prevents water from reaching the waste and thus dissolving and transporting waste components, (b) a chemical barrier that prevents the movement of waste components by chemical reaction to remove the waste components from the water, or (c) a combination of chemical and physical barriers.

Many barriers have been developed for waste isolation. ${ }^{2}$ These include physical barriers such as Portland-pozzolana cement systems, lime fly ash pozzolana systems, thermo-encapsulation materials, sodium silicate cements, clay waste pit liners, organic binding using acrylate or urethane, and chemical barriers such as sorption materials, used mainly to immobilize free liquids, zeolite minerals, and possibly iron oxyhydroxide ${ }^{1}$ materials for application to groundwater systems. Except for clay, iron oxyhydroxide, and some of the zeolite minerals, none of these materials is in thermodynamic equilibrium with the natural environment. This means that these waste isolation materials must degrade and lose effectiveness with time. If the rate of degradation is less than the decomposition rate of, for example, encapsulated radionuclide or organic materials, then the encapsulation strategy is successful. If the contaminants do not degrade with time, then the 
contaminants will be released to the environment as the waste encapsulation material degrades. In this case, the contaminant release rate must be at an acceptable level.

At the INEL and other DOE waste sites, the problem is complicated because the waste includes transuranic element contamination that is predicted to remain hazardous for thousands of years (plutonium half-life is 24,000 years). This requires that the waste isolation material also remain effective for thousands of years. None of the materials mentioned above are specifically chosen to be in thermodynamic equilibrium with their environment and, therefore, most of them must eventually degrade. Failure of conventional containment systems is virtually guaranteed if the waste isolation materials are required to have an effective life time longer than 10,000 years, for example.

\subsubsection{Past INEL and DOE In Situ Waste Encapsulation Demonstrations}

The INEL has field demonstrated in situ grouting ${ }^{3-5}$ and cryogenic containment. The in situ grouting activity demonstrated dynamic compaction and gravity injection of a particulate microfine cement grout into a simulated buried waste pit using the Richland Hanford Operations technique. The technique could not be recommended for application to buried waste because the particulate grout did not penetrate the voids in the soil, even though the voids in the waste were grout filled. ${ }^{3,4}$

Acrylamide grouts, organic polymer waste encapsulation materials, which are finer in grain structure and perhaps would penetrate the soil, were not considered for application in arid sites because of potential desiccation cracking. Their use has been prohibited by the Environmental Protection Agency (EPA). ${ }^{6}$ Nontoxic organic formulations are now available. ${ }^{a}$

A recent INEL study ${ }^{7}$ involved jet grouting Portland cement into simulated buried waste. The jet grouting operation successfully created a monolithic structure filling $100 \%$ of the void space.

\subsubsection{Nature of Test}

The test is a set of bench-scale experiments to evaluate the application of iron oxide (and related compounds) as in situ waste encapsulation materials at the INEL.

The specific chemical reaction proposed for development and field demonstration in the INEL Cold Test Pit is the reaction:

$2 \mathrm{FeSO}_{4} \cdot 7 \mathrm{H}_{2} \mathrm{O}+2 \mathrm{Ca}(\mathrm{OH})_{2}+1 / 2 \mathrm{O}_{2}=$ intermediate insoluble products

$=\mathrm{Fe}_{2} \mathrm{O}_{3}+2 \mathrm{CaSO}_{4} \cdot 2 \mathrm{H}_{2} \mathrm{O}+14 \mathrm{H}_{2} \mathrm{O}$.

a. Draft report by J. L. Mayberry and L. M. Dewitt, Technical Area Status Report for Low-level Mixed Waste Forms, Vol. 1 and 2, DOEIMWIP Science Applications International, OTD-DOE Mixed Waste Integrated Program, 1992. 
Note that the iron is initially in the reduced or ferrous state and is oxidized to the ferric state by oxygen from air (or groundwater if applied below the water table). The products of the reaction as written are the minerals hematite and gypsum, the thermodynamically stable products in oxidizing conditions. In anaerobic aqueous environments the reaction is similar except magnetite is the stable iron oxide. Under very reducing conditions, iron sulphide would be a stable phase. The intermediate products are also chemically very insoluble ${ }^{8}$ in water and are expected to include the materials maghemite, a defect spinel with nominal $\mathrm{Fe}_{2} \mathrm{O}_{3}$ composition, ferric oxyhydroxide $[\mathrm{FeO}(\mathrm{OH})]$, and calcium sulphate hydrate $\left(\mathrm{CaSO}_{4} \bullet 1 / 2 \mathrm{H}_{2} \mathrm{O}\right)$. The rate controlling reactions are expected to be the very slow dehydration of $\mathrm{FeO}(\mathrm{OH})$ to hematite.

In principle, it is possible to introduce iron oxide precipitating materials into buried waste and to decrease the permeability of the soil matrix by using one or more of several different reagents. The above reaction is considered to be the most suitable for field application at the INEL and was chosen for initial trials for several reasons. The reactants are inexpensive industrial and agricultural reagents and pose no special handling hazards. The reaction is expected to produce a minimum solution plume during field application. This is an important consideration because application at the SDA would probably not be permitted to produce more than, at most, a very small fluid plume; one which can be easily controlled using soil de-watering techniques such as the electrokinetic methods ${ }^{2}$ used by the construction industry. Finally, most appropriate iron-containing solutions and reagents are acidic, a property that has the potential for mobilizing certain hazardous constituents during application. In contrast, by combining a sulphate and a hydroxide, the proposed reaction is self-neutralizing and the $\mathrm{pH}$ of the treatment materials can be controlled by simple adjustment of the sulphate-hydroxyl ratio. The performance of the materials is expected to be insensitive to the exact proportions of constituents; slightly excess ferrous sulphate would react with natural calcite in the waste pits to produce iron oxide and gypsum and excess calcium hydroxide would react with natural carbon dioxide in the groundwater and air to produce calcite, exactly as calcite is being produced naturally at the SDA. One important aspect of the proposed materials is that the reagents are applied in the form of viscus fluids that will probably require high pressure, dynamic injection (i.e., "jet grouting") into the buried waste.

The proposed waste isolation reaction is thought to be directly applicable to the isolation of buried waste at the SDA. This is indicated by the following SDA properties. The SDA buried waste is surrounded and covered by soil in pits and trenches that are approximately 7 to $10-\mathrm{m}$ deep and overlay a volcanic rock sequence of basalt. The soil and buried waste are completely in the vadose zone and are $190 \mathrm{~m}$ above the water table. The $\mathrm{pH}$ of water in contact with SDA soil is about 8 or above. ${ }^{9}$ This is consistent with the presence of calcite in the INEL soils. ${ }^{10}$ The oxygen content of soil gas measured at the $110 \mathrm{ft}$ interbed was found to be identical to air. Vertical permeability measurements ${ }^{11}$ in the volcanic sequence below the SDA indicate that air moves in and out of the subsurface below the SDA to depths of at least $80 \mathrm{~m}$. Both observations indicate that, on a scale of meters and larger, the oxidation-reduction properties are very oxidizing, equivalent to air. On a local scale, for example directly beside or inside a steel drum filled with machine cutting oil, the conditions are anaerobic and will continue to be so as long as the metallic iron or oil exist; they buffer the local oxidation-reduction conditions to low values.

b. W. C. Downs, Lockheed Idaho Technologies Company, unpublished data. 
Rust and corrosion on the surfaces of buried iron objects indicate that the effect is restricted to within a few millimeters of the surface of the object. The effects of oil or grease are probably also restricted to a small zone. The presence of rust on the steel drums indicates that the local groundwaters are iron saturated and incapable of dissolving additional iron.

Review of the composition ${ }^{12-15}$ of the buried waste at the SDA suggests that the waste materials are compatible with the proposed waste isolation reactions. Metallic iron objects and oils, greases, and similar reducing agents are expected to control the local oxygen fugacity as discussed above, but are not expected to significantly affect the performance of the waste isolation material. Nitrate salts are oxidizing components and will probably increase the rate of the waste encapsulation reaction, but are expected to have no other effect. The waste isolation materials should have no reaction with solvents such as carbon tetrachloride.

In summary, the scope of the project is to carry out a set of experiments that would prove or disprove the notion that iron oxide precipitating materials can produce a waste encapsulation material suitable for application at the INEL.

\subsection{Technology Need}

The technology addresses one primary need for buried waste, specifically the need for longterm (in terms of geologic time) systems for the containment and isolation of buried waste from the environment. The primary need for this technology is identified by Environmental Restoration Waste Area Group 7 (WAG-7); Keith Daum (208-526-6902) and Doug Mckenzie (208-526-2977) are contact points. The technology also provides data applicable to a secondary need, namely the need for ex situ encapsulation of stored and retrieved wastes such as those at the INEL and other DOE sites.

A potential secondary waste stream generated by the application of this technology may be excess water in or near the waste site. Field testing must be carried out to determine how much water is "excess" and how this water will be controlled in the field. 


\section{TEST OBJECTIVES}

The objective of the laboratory program was to generate a body of data sufficient to show whether synthetic analogues of natural iron oxide cements are practical waste isolation materials for application at the SDA and whether sufficient data are available to carry out a full-scale field demonstration in FY-95. The laboratory program would test the hypothesis that iron oxide (including oxyhydroxides, hydroxides, and similar iron oxide materials) are possible in situ waste encapsulation materials and are appropriate for field testing for possible application at the SDA.

Application of the iron oxide waste encapsulation materials at the SDA requires laboratorygenerated information about the following properties:

1. Effect of encapsulation treatment on hydraulic conductivity of INEL soil and simulated waste.

2. Compressive strength of treated INEL soil and the waste encapsulation material.

3. Mineralogy and microstructure of waste encapsulation material.

4. Compatibility of waste encapsulation material with possible waste materials, to include nitrates, machine cutting oil, and metallic iron.

5. Leachability of hazardous constituents encapsulated by the waste isolation material.

6. Application methods of iron oxide encapsulation materials to INEL buried waste. Field testing of jet grouting of soil/waste matrix took place in FY-94 as the Innovative Grout/Retrieval Demonstration. ${ }^{7}$ This technology is the most likely one for injection of the encapsulating materials.

\subsection{Data Quality Objectives}

The data quality objectives are a set of qualitative and quantitative statements that specify the quality of the data required to determine whether synthetic analogues of natural iron oxide cements are practical waste isolation materials for application at the SDA and whether sufficient data are available to carry out a full-scale field demonstration in FY-95. The determination of the practicality of iron-oxide-based waste isolation materials can be made from the data generated by items 1-5 above. The determination of the possibility of performing a full-scale field demonstration in FY-95 can be made from item 6 above.

The effect of iron oxide treatment on the hydraulic conductivity of INEL soil and buried waste was evaluated by measuring the hydraulic conductivity of untreated INEL soil with treated INEL soil in the laboratory and comparing the results. The precision of such measurements is usually a factor of 5 to 10 . A significant difference between treated and untreated soil samples would be at least one order of magnitude difference in permeability. A reasonable target hydraulic conductivity value for soils treated with the waste isolation material is $10^{-6} \mathrm{~cm} / \mathrm{sec}$ 
compared to the hydraulic conductivity of undisturbed Radioactive Waste Management Complex (RWMC) soil values ${ }^{16}$ of $10^{-4}$ to $10^{-5} \mathrm{~cm} / \mathrm{s}$.

The treated INEL soil compressive strength measurements was evaluated relative to the Nuclear Regulatory Commission (NRC) requirement (50 psi) for waste forms for the containment of radioactive waste. A determination of a significant difference between the NRC minimum and the measured value will be achieved by a measurement precision of $\pm 10 \%$.

The mineralogy and microstructure characterization are required to provide a minimum understanding of the chemical and physical nature of the waste isolation materials and to assess the penetration of the waste form between the simulated waste and soil. It was expected that some adjustment would be needed among the amount of soil, waste isolation material, water, and, perhaps, purity of the reagents. The necessary information was obtained using $x$-ray powder diffraction (XRD) for identification of the crystalline phases present in quantities greater than 2 vol\% and a scanning electron microscopy (SEM) was used to photograph the microstructure at magnifications up to 3,000 times. Petrographic observations were made from the photographs and recorded in a bound laboratory notebook.

Information concerning the compatibility of the waste isolation material with possible waste found in the SDA is necessary to predict the behavior of the waste encapsulation material when applied at the SDA. The primary concern is chemical reaction produced by variation in the oxidation-reduction potential in the buried waste environment. This was evaluated by determining the mineralogy and microstructure of waste encapsulation materials in contact with potassium nitrate, which causes an oxidizing environment, and machine cutting oil and metallic iron, both of which produce reducing environments.

Leachability of hazardous constituents encapsulated by the waste isolation material was determined using the standard TCLP leach test. ${ }^{6}$ The results were evaluated relative to the EPA minimum standards for toxic metals in water. ${ }^{6}$

Methods for application of the waste encapsulation material at the SDA are required. The application method is a function of the properties of the reagents used to formulate the iron oxide waste encapsulation materials and includes qualitative determination of setting time, estimates of heat generated and temperatures reached during reaction, slurry viscosity, chemical compatibility with the injection equipment, physical stability of the reagents, and assessment of possible application techniques relative to these properties. 


\section{EXPERIMENTAL DESIGN AND PROCEDURES}

The laboratory program generated a body of data to test the hypothesis that iron oxide precipitates (including oxyhydroxides, hydroxides, and similar iron oxide materials) together with gypsum are possible in situ waste encapsulation materials and are appropriate for field testing for possible application at the SDA. The test program is described in In Situ Encapsulation Bench Scale Demonstration Test Plan (for TTP-ID 142012). ${ }^{17}$ No deviations from the test plan were made.

The tests include the following activities:

- Characterization of test reagents

- Hydraulic conductivity (permeability) tests

- Waste compatibility tests and compressive strength tests

- $\quad$ Leach testing

- Field application parameters.

The procedures used to carry out each of these activities are described below.

\subsection{Reagent Characterization}

The characterization of test reagents are a set of measurements to determine the nature of the reagents used during the study. The purpose is to ensure that the reactions, tests, measurements, etc., are in fact being carried out on the materials $\mathrm{FeSO}_{4} \cdot 7 \mathrm{H}_{2} \mathrm{O}$ and $\mathrm{Ca}(\mathrm{OH})_{2}$. The reagents are agricultural grade, identical to those used in actual application in the field, and are expected to contain some level of impurity. The ferrous sulphate heptahydrate was manufactured by QC Corp. in Baltimore, Maryland, and the calcium hydroxide was manufactured by Ash Grove Cement in West Portland, Oregon.

X-ray powder diffraction was used to identify the major crystalline phases. The ferrous sulphate hydrate starting material is primarily melanterite $\left(\mathrm{FeSO}_{4} \cdot 7 \mathrm{H}_{2} \mathrm{O}\right)$, with several ferrous sulphate hydrate compounds present in small amounts including rozenite ( $\mathrm{FeSO}_{4} \bullet 4 \mathrm{H}_{2} \mathrm{O}$ ), iron sulphate hydrate $\left(\mathrm{Fe}_{6} \mathrm{~S}_{8} \mathrm{O}_{33} \cdot 2 \mathrm{H}_{2} \mathrm{O}\right)$, minor amounts of siderotil $\left(\mathrm{FeSO}_{4} \cdot 5 \mathrm{H}_{2} \mathrm{O}\right)$, and probably, in lesser amounts, other ferrous sulphate compounds with other water contents. The slaked lime [calcium hydroxide, $\mathrm{Ca}(\mathrm{OH})_{2}$ ] contains trace amounts of calcite $\left(\mathrm{CaCO}_{3}\right)$. A description of the phase identification procedure using x-ray deffraction (XRD) is given in Appendix $A$.

To determine if toxic metals were present in the reagents, qualitative $\mathrm{x}$-ray fluorescence (XRF) analysis was carried out to estimate the concentration of elements with an atomic number greater than 11 (sodium). The ferrous sulphate contained trace amounts of chromium, manganese, and zinc. The slaked lime contained minor amounts of silicon, phosphorus, 
manganese, iron, copper, zinc, strontium, yttrium, and zirconium. The results of the XRF analysis and details of the method are given in Appendix $B$.

The amount of ferrous sulphate necessary to react stoichiometrically with the slaked lime to produce gypsum and iron oxide(s) was determined by measuring the amount of slaked lime necessary to be added to a known ferrous sulphate solution so that the final solution $\mathrm{pH}$ was about seven. The ratio by weight was found to be 3.76 to 1 (i.e., a molar ratio of 1:1). The water content of the reagents was determined by weight-loss on heating.

Two soils were used in the test program. One is a composite sample made by mixing equal volumes of 14 soil samples collected from locations at the INEL. The sample locations include Experimental Breeder Reactor-1 (EBR-1), Army Reactor Area (ARA), Naval Reactor Facility (NRF), and Idaho Chemical Processing Plant (ICPP), two sites at the Central Facility Area (CFA) and RWMC, and three sites at Test Area North (TAN) and the Test Reactor Area (TRA). Sample locations were selected from INEL surficial geology maps. ${ }^{18}$ Each sample was catalogued, dried, and pulverized to 325 mesh. $^{19}$ According to analysis using XRD, the composite soil sample contains predominately quartz $\left(\mathrm{SiO}_{2}\right)$ and sodium rich plagioclase, with lesser amounts of sanidine (potassium rich feldspar), and clay minerals of the smectite-kaolinite families. This material was used in all testing except the hydraulic conductivity tests.

The soil used in the hydraulic conductivity test was collected in exactly the same place and in the same manner as the materials that are being used to backfill the SDA at the present time. These materials are not, strictly speaking, soils, but rather lacustrian and eolian sediments located in the Lost River settling areas in and around the RWMC. A detailecl description of the sample location and excavation method is given by Weidner. ${ }^{20}$ These soil-like materials were used as collected without additional processing to provide a material as nearly like that in the SDA as possible. Size analysis of such unprocessed material indicated that $42.4 \mathrm{wt} \%$ is $25.0-2.36 \mathrm{~mm}$, $13.0 \mathrm{wt} \%$ is $1-2.4 \mathrm{~mm}, 6 \mathrm{wt} \%$ is $0.6-1 \mathrm{~mm}, 5.6 \mathrm{wt} \%$ is $0.15-0.3,15.4 \mathrm{wt} \%$ is $0.075-0.15 \mathrm{wt} \%$, $-0.075 \mathrm{~mm}$ is $11 \mathrm{wt}^{10} .^{10}$ The mineralogical composition ${ }^{10}$ is about 37 wt\% quartz, $48 \mathrm{wt} \%$ clay minerals, and $10 \mathrm{wt} \%$ calcite, with other minor constituents.

\subsection{Hydraulic Conductivity Measurements}

The objective of the hydraulic conductivity tests was to determine the effect of the addition of the iron oxide waste isolation material on the hydraulic conductivity of sediments and soils likely to be found at the SDA. Hydraulic conductivity tests were carried out, in duplicate, on four soil and soil/iron waste isolation material mixtures at the Colorado State University Geotechnical Engineering Laboratory.

The iron oxide waste isolation material was formulated by mixing agricultural grade ferrous sulphate $\left(\mathrm{FeSO}_{4} \cdot 7 \mathrm{H}_{2} \mathrm{O}\right)$ with agricultural grade slaked lime $\left[\mathrm{Ca}(\mathrm{OH})_{2}\right]$ in the ratio 3.76 to one by weight. This proportion is the stoichiometric requirements for the reaction $2 \mathrm{FeSO}_{4} \cdot 7 \mathrm{H}_{2} \mathrm{O}+$ $2 \mathrm{Ca}(\mathrm{OH})_{2}+1 / 2 \mathrm{O}_{2}=2 \mathrm{FeO}(\mathrm{OH})+2 \mathrm{CaSO}_{4} \cdot \mathrm{H}_{2} \mathrm{O}+10 \mathrm{H}_{2} \mathrm{O}$ and was determined by experiment and calibration of the starting materials.

c. Personal communication, E. B. McNew, Lockheed Idaho Technologies Company. 
The iron waste isolation material was manually mixed with the soil in the ratio of $1: 2$ by weight in lots of about $10 \mathrm{lb}$. Known amounts of water were added and blended manually with the mixtures to produced a thick slurry. The slurry was loaded into molds similar in size to standard proctor molds (ASTM D698). Four specimens were prepared in duplicate. Two specimens and their duplicates were untreated soil and two, with duplicates, were soil treated with waste isolation material. One untreated soil and one treated soil, with duplicates, were air dried at $103^{\circ} \mathrm{C}$ to constant weight. The other treated-untreated soil pair, together with duplicates, were sealed and maintained saturated with water.

Eight hydraulic conductivity tests were conducted on four different types of specimens using flexible wall permeameters to determine the hydraulic conductivity of each of the eight specimens. The measurements were performed in general accordance with test method C of ASTM D5084-90, the standard test method for measuring hydraulic conductivity of saturated porous materials using a flexible wall permeameter with a falling headwater/rising tailwater evaluation. However, in order to carry out the tests in a timely manner the procedure for this test program was modified slightly from the standard test method without a significant loss of precision or accuracy. The detailed description of the measurement procedures is given in Appendix $\mathrm{C}$.

\subsection{Waste Compatibility Tests and Compressive Strength Tests}

The objectives of the waste compatibility and compressive strength tests were to obtain information to allow a determination of whether or not the iron oxide waste encapsulation material would be stable in the presence of contaminant likely to be found at the SDA and if the strength of the waste encapsulation material would be sufficient to prevent collapse of the void space in the buried waste at the SDA. The required data include characterization of the crystalline phases and microstructure of the iron oxide waste isolation materials in the chemical environments likely to be encountered at the SDA and measurements of the effect of different kinds of waste on the strength of the treated soils.

Iron in the waste isolation material may be found in several different chemical forms depending on the oxidation-reduction conditions of the waste-site environment. Nitrate compounds cause oxidizing conditions that favor the ferric oxidation state while metallic iron and cutting oil create relatively reducing conditions in which ferrous iron is often the most stable oxidation state of iron. The effect of water compared to air, and the effect of machine cutting oil, nitrate compounds, and metallic iron on the mineralogy and microstructure were determined using XRD and the SEM. The XRD provides information about the kind of crystalline phases present and the SEM shows the sample microstructure such as porosity, grain size, and shape.

The test specimens containing the waste isolation material were prepared in the normal ratio of 3.76 to 1 by weight of iron sulphate heptahydrate to slaked lime together with 54 wt\% soil or soil-waste mixture. Compositions listed as containing nitrate, oil, or iron metal were prepared by mixing the required amount of reagent grade potassium nitrate, Texaco Regal Oil, or reagent grade, 325 mesh, metallic iron powder into the waste isolate material or the waste isolation and soil mix as appropriate. The mixtures were prepared dry and then a measured amount of water was added to produce a thick slurry. One set of samples was air dried to constant weight. A second set of samples was sealed while wet into sample containers and not allowed to dry. The major crystalline phases present in both sets of samples was determined using XRD. The SEM 
was used to make photomicrographs showing the microstructure of coherent lumps of the dried samples.

Materials for compressive strength measurements were made in exactly the same way or were splits of the original preparation. The wet mixes were placed into glass cylinders having a length of about $3.5 \mathrm{~cm}$ and diameter of about $1 \mathrm{~cm}$ and air dried to constant weight, usually about 10 days. A thin coat of vacuum grease was used as a release agent on the walls of the cylinders. After drying, the cylinders were extruded from the glass molds and carefully sanded by hand so that the shape of the material was a right cylinder. Cylinders with obvious voids, cracks, or other defects were discarded. The length and diameter of the test specimens were measured. The compressive force necessary to cause failure was measured using an Instrom instrument at the IRC. Compressive strength measurements were made according to ASTM C-3986. ${ }^{21}$

\subsection{Leach Testing}

A set of Toxicity Characteristics Leach Procedure (TCLP) leach tests were carried out to determine if the iron waste isolation material would prevent hazardous metals from being leached from INEL soil.

The iron oxide waste isolation material was prepared by mixing agricultural grade ferrous sulphate $\left(\mathrm{FeSO}_{4} \cdot 7 \mathrm{H}_{2} \mathrm{O}\right)$ with agricultural grade slaked lime $\left[\mathrm{Ca}(\mathrm{OH})_{2}\right]$ in the proportion by weight of 3.76 to 1 .

Four samples were tested. One sample was INEL soil with no added material. A second sample was INEL soil into which was mixed powdered, reagent grade oxides of silver $\left(\mathrm{Ag}_{2} \mathrm{O}\right)$, arsenic $\left(\mathrm{As}_{2} \mathrm{O}_{3}\right)$, barium $(\mathrm{BaO})$, cadmium $(\mathrm{CdO})$, chromium $\left(\mathrm{Cr}_{2} \mathrm{O}_{3}\right)$, mercury $(\mathrm{HgO})$, lead ( $\left.\mathrm{PbO}\right)$, and selenium $\left(\mathrm{SeO}_{2}\right)$ in proportions such that $1 \mathrm{wt} \%$ of each metal was added. The third and fourth samples were made by mixing the soil-hazardous metal oxide mixture with 56 and 48 wt\% percent of the iron oxide waste isolation material. Known amounts of water, typically about $50 \mathrm{wt} \%$, were added to the mixtures to produce a thick slurry. All miving was done by hand. The wet mixtures were then dried in air at $103^{\circ} \mathrm{C}$ to constant weight.

Ten grams of each sample were mixed with $200 \mathrm{~mL}$ of dilute acetic acid $(0.1 \mathrm{~N}$, TCLP solution number two) in an Erlenmeyer flask and stirred for 24 hours. The leachate was withdrawn from each flask and filtered. These four solutions, together with a $0.01 \mathrm{~N}$ acetic acid solution, were diluted by a factor of 10 and analyzed for $\mathrm{As}, \mathrm{Ag}, \mathrm{Ba}, \mathrm{Cd}, \mathrm{Cr}, \mathrm{Hg}, \mathrm{Pb}$, and $\mathrm{Se}$ using an inductively coupled plasma- mass spectrometer in the Idaho Research Center. Kyle Messic was the analyst and the EPA protocol ${ }^{6}$ for the TCLP analysis was used. The samples disintegrated into powder in the leach solution and did not require prior grinding.

\subsection{Field Application Parameters}

The amount of ferrous sulphate required to react stoichiometrically with the slaked lime to produce gypsum and iron oxide(s) was determined by titration. Six titrations were performed. The six ferrous sulphate solutions were prepared by dissolving $0.1-0.5$ grams in $5 \mathrm{~mL}$ of water. Three slaked lime $\left[\mathrm{Ca}(\mathrm{OH})_{2}\right]$ solutions were prepared by dissolving $0.15-0.19 \mathrm{~g}$ of the slaked lime 
into $100.0 \mathrm{~mL}$ of water. The concentration of lime is below, but close to the saturation point. A standard laboratory $\mathrm{pH}$ meter was used to monitor the titration process and was calibrated for each set of titration measurements.

The application of the ferrous sulphate and slaked lime reagents to waste encapsulation problems in the field requires some sort of injection or application system. Consequently, information about the properties of the solutions and reagents is necessary in order to choose or develop a method for applying the materials in the field. Concentration and $\mathrm{pH}$ of reagents in solution or slurry were determined as part of other tests as describe above. Waste isolation material setting time was estimated by mixing the reagents wet and measuring the temperature of the solutions as a function of time. The temperatures generated by the reaction was measured starting at room temperature and also with the reagents cooled and mixed in an ice bath. The mixtures were prepared by hand and the scientist observed and described the nature of the mixture during the setting reaction. Temperatures, measured to $\pm 1^{\circ} \mathrm{C}$, of the mixtures were recorded continuously during the mixing and setting processes using an electronic laboratory thermometer. These data allowed the determination of mixture set time at standard room temperatures and also at the lowest routinely attainable temperature for field application. The data can be used to select and/or design field application procedures and apparatus.

Viscosity measurements of the reagents mixed with water were determined for future application using jet grouting or other application method. Slurries of the reagents were prepared as a function of water content and measured using a Brooks viscometer according to the instructions of the manufacturer. 


\section{QUALITY ASSURANCE}

The test followed the quality program plan QPP-044 and quality level B.

All laboratory data and observations were recorded in a bound laboratory notebook that was dated and signed daily by the person doing experiments. Most of the data were generated either by qualitative observation or were measurements made directly by an observer. Data of this type were recorded directly into a bound laboratory notebook with sequentially number pages. Other data types such as strip charts and electronic data were labeled and identified in the laboratory notebook. The principal investigator reviewed the procedures and raw data at least twice per week for concurrence with the test plan. Reagents labels were recorded in the notebook. Laboratory activities were photographically documented. A second bound laboratory notebook was used to record date, time, subject, and photograph film frame number for each photograph. It was signed by the person tanking the photographs and entries were quality assurance checked and signed by a second person. Samples were stored in permanent, labeled containers. The data were recorded in the form most appropriate for the measurement being made.

Most of the tests are qualitative observations except for the leach testing, hydraulic conductivity, compressive strength and related measurements that were prepared and analyzed in duplicate or triplicate as appropriate. 


\section{HEALTH AND SAFETY}

Safety is of utmost concern throughout all experiments, tests, and demonstrations. It is company policy to take every practical precaution to protect the health of the employees. Areas of safety and training are laboratory and waste management.

The tests were carried out in the laboratory facilities of the IRC. No work involving radioactive or hazardous material was carried out except for the TCLP tests that used less than 5 grams of hazardous material. Laboratory safe practices were followed as described in the Standard Practices Manual, Science and Technology Department. Subsections that apply to this report in General Laboratory Practices include "Eye Protection and Protective Clothing," "Laboratory Safety," "Laboratory Hood Use," and "Laboratory Training. ${ }^{\text {22 }}$ 


\section{ENVIRONMENTAL OVERVIEW}

All experiments were carried out using standard laboratory practices. The amount of materials used in the experiments was the minimum amount necessary to achieve the goals of the test program. This allowed the necessary data to be taken, but minimized waste because experiments were not needlessly duplicated. The results of this effort resulted in complete protection of the environment. In fact, the reagents used in this study are agricultural products intended to restore environmentally hammered crop, meadow, and forest areas and the authors intends to so apply the surplus reagents resulting from this program as they were supplied at no cost by Great Western Chemical Co. in Idaho Falls, Idaho. 


\section{TEST RESULTS}

The results of the test program are described in this section.

\subsection{Waste Compatibility and Compressive Strength}

\subsubsection{Phases Present}

The phases identified in the tests specimens include goethite $[\mathrm{FeO}(\mathrm{OH})]$, green rust $\left(\mathrm{Fe}_{2} \mathrm{O}_{3} \cdot \mathrm{H}_{2} \mathrm{O}\right)$, an iron sulphate hydrate with iron in both the ferric and ferrous oxidation states $\left(\mathrm{Fe}_{2} \mathrm{~S}_{2} \mathrm{O}_{9} \cdot 5 \mathrm{H}_{2} \mathrm{O}\right)$, gypsum $\left(\mathrm{CaSO}_{4} \cdot 2 \mathrm{H}_{2} \mathrm{O}\right)$, calcium sulphate hydrate $\left(\mathrm{CaSO}_{4} \cdot 2 / 3 \mathrm{H}_{2} \mathrm{O}\right)$, together with the soil minerals. The phases are analogous to similar minerals forming by natural processes in soils.

The phases identified in the samples by XRD are given below. Note that the chemical formulas are nominal compositions only; XRD measurements as used here gave crystallographic information only and the composition of the phases was inferred.

The ferrous sulphate hydrate starting material was made up of several ferrous sulphate hydrate compounds. It is predominately melanterite $\left(\mathrm{FeSO}_{4} \bullet 7 \mathrm{H}_{2} \mathrm{O}\right)$, but also includes rozenite $\left(\mathrm{FeSO}_{4} \bullet 4 \mathrm{H}_{2} \mathrm{O}\right)$, iron sulphate hydrate $\left(\mathrm{Fe}_{6} \mathrm{~S}_{8} \mathrm{O}_{33} \bullet 2 \mathrm{H}_{2} \mathrm{O}\right)$, minor amounts of siderotil $\left(\mathrm{FeSO}_{4} \cdot 5 \mathrm{H}_{2} \mathrm{O}\right)$ and probably, in lesser amounts, other ferrous sulphate compounds with other water contents. The slaked lime [calcium hydroxide, $\mathrm{Ca}(\mathrm{OH})_{2}$ ] contains minor amounts of calcite $\left(\mathrm{CaCO}_{3}\right)$. The soil sample contains predominately quartz $\left(\mathrm{SiO}_{2}\right)$, and sodium rich plagioclase, with lesser amounts of sanidine (potassium rich feldspar), and clay minerals of the smectite-kaolinite families.

The term "wet" indicates that the sample was not allowed to dry out and was analyzed in the wet state. "Dry," on the other hand, indicates that the sample was thoroughly air dried to constant weight prior to analysis. SEM photographs were taken of "dry" samples only.

The phases identified in the test specimens are shown in Table 1. Gypsum $\left(\mathrm{CaSO}_{4} \cdot 2 \mathrm{H}_{2} \mathrm{O}\right)$ is a common sample constituent. All wet samples contained gypsum, but three dry samples did not. Calcium sulphate hydrate $\left(\mathrm{CaSO}_{4} \bullet 2 / 3 \mathrm{H}_{2} \mathrm{O}\right)$ is found exclusively in dry samples, including the three samples that did not contain gypsum. This distribution of the gypsum and calcium sulphate hydrate phases is attributed to the kinetics of competing reactions. Sufficient water was present in the wet samples for a long enough period of time for the calcium sulphate phases to hydrate completely to gypsum. In the case of the dry samples, the drying process could be faster or slower depending on laboratory conditions. In some cases (samples 2, 8, and 9), sufficient time allowed the calcium sulphate to hydrate to gypsum. In other cases (samples 4 and 15), both calcium sulphate phases are present, indicating that the reaction $\mathrm{CaSO}_{4} \cdot 2 / 3 \mathrm{H}_{2} \mathrm{O}+4 / 3 \mathrm{H}_{2} \mathrm{O}$ $=\mathrm{CaSO}_{4} \cdot 2 \mathrm{H}_{2} \mathrm{O}$ was not completed before the water in the sample was removed by evaporation. The absence of gypsum in three samples $(11,13$, and 6$)$ indicate that the water was lost from the sample before the gypsum-forming reaction took place. 
The iron-containing phases have a similar distribution. Green rust $\left(\mathrm{Fe}_{2} \mathrm{O}_{3} \bullet \mathrm{H}_{2} \mathrm{O}\right)$ is found only in wet samples $(1,3,10$, and 14). Goethite $[\mathrm{FeO}(\mathrm{OH})]$ is found in five dry samples $(8,9,11$, 13 , and 15), but only one wet sample (7). Distribution of the iron-containing minerals suggests a mechanism similar to gypsum formation. Goethite is thermodynamically stable compared to green rust, indicating that the reaction, $\mathrm{Fe}_{2} \mathrm{O}_{3} \cdot \mathrm{H}_{2} \mathrm{O}=2 \mathrm{FeO}(\mathrm{OH})+\mathrm{H}_{2} \mathrm{O}$ should take place regardless of the presence or absence of additional water. The occurrence of goethite in only one wet sample indicates that the drying process accelerates the goethite-forming reaction.

The presence of iron sulphate hydrate $\left(\mathrm{Fe}_{2} \mathrm{~S}_{2} \mathrm{O}_{9} \cdot 5 \mathrm{H}_{2} \mathrm{O}\right)$, which contains iron in both ferrous and ferric states, indicates that the samples containing this iron compound were not completely oxidized to the ferric state, the stable form of iron in oxides and hydroxides in equilibrium with air. It is found in both wet $(3,5$, and 12$)$ and dry samples (8 and 9$)$. Its presence is also judged to be due to relatively slow reaction rates, indicating that the formation of gypsum and iron oxide compounds is not complete or in equilibrium with air.

The presence or absence of nitrate, oil, or metallic iron does not appear to have a significant effect on the crystalline compounds found in the samples. Metallic iron or machine cutting oil can buffer the oxygen fugacity of the samples to relatively low values and can cause iron compounds to be in the ferrous state, however, this did not occur. The samples originally containing metallic iron now contain ferric iron compounds including green rust $\left(\mathrm{Fe}_{2} \mathrm{O}_{3} \bullet \mathrm{H}_{2} \mathrm{O}\right.$, sample 14) and goethite $[\mathrm{Fe}(\mathrm{OH})$, samples $7,8,15]$. Metallic iron was not identified in any of the samples. Similarly, the presence of oil or nitrate appears to have had no effect on the sample mineralogy.

Iron compounds were not identified in three dry samples $(2,4$, and 6$)$, containing soil. The samples are yellow-orange in color and identical in appearance to all the other dry samples. The yellow-orange color indicates that the iron hydroxide compounds are present. It is probable that the soil diluted and complicated the XRD data so that the iron compounds could not be identified. This interpretation is indicated by comparing the dry, waste isolation material (sample 9) with the dry, waste isolation material mixed with soil. Goethite and iron sulphate hydrate were iron compounds identified in the dry waste isolation material whereas no iron compounds were identified in the same material with soil added (sample 2).

SEM photographs were taken of the dry samples. The photomicrographs show that all samples are porous and that the individual particles do not interlock (see Figures 1 and 2). The microstructures are virtually identical for all samples and appear to be unaffected by the presence of soil, metallic iron, potassium nitrate, or oil. All samples contain rod shaped (about $0.5 \times$ $5 \mu \mathrm{m}$ ), and plate-like (up to about $10 \mu \mathrm{m}$ diameter) grains together with irregularly shaped material. The lack of interlocking particles contributes to low dry strength (compared to concrete, for example) and allows the sample to physically disintegrate into a mud-like material when wet. Sample preparation with less water would probably decrease the amount of porosity and increase the likelihood of interlocking grain growth during the setting/drying period of soils treated with the waste isolation material. 

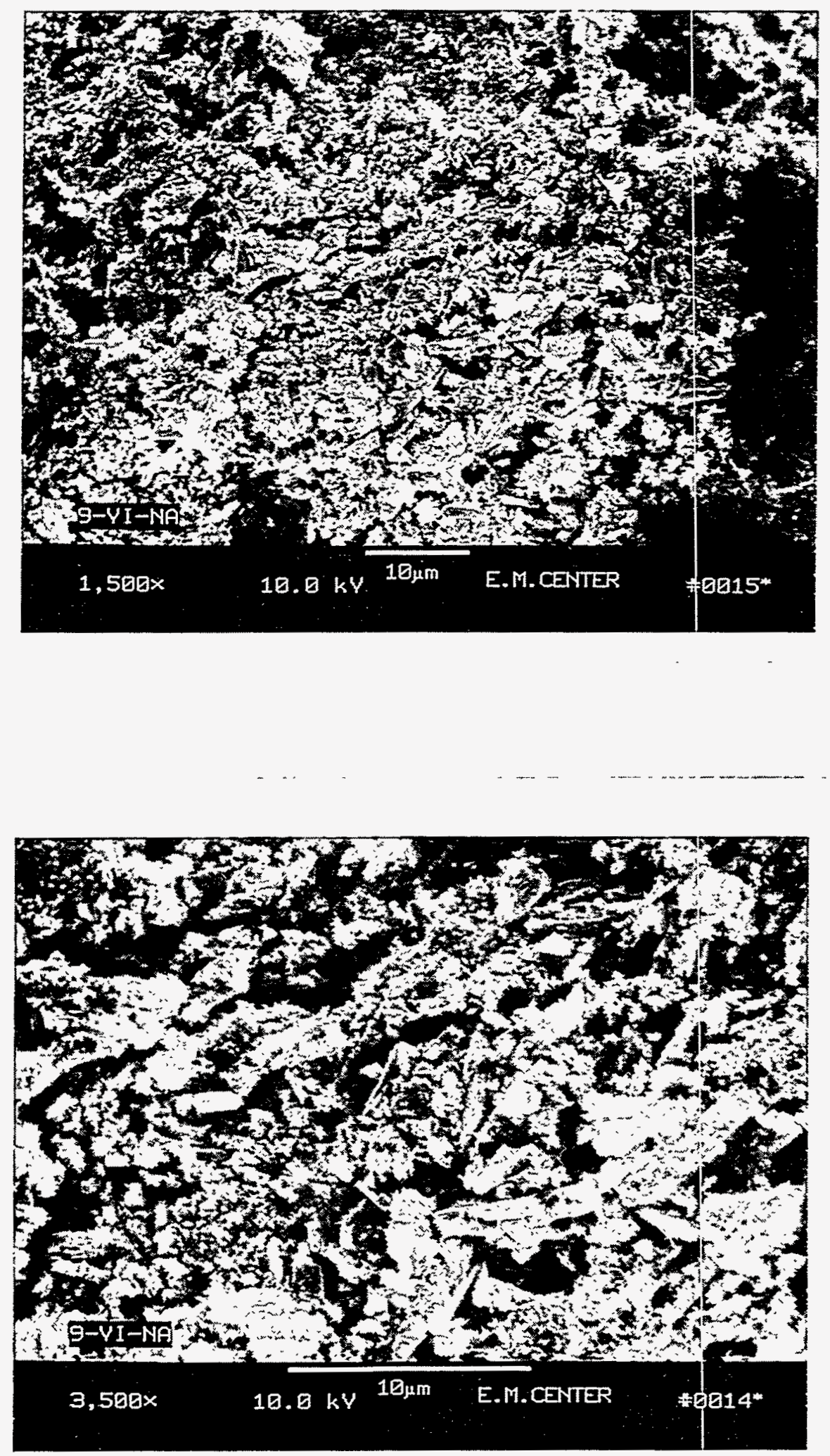

Figure 1. Photomicrographs of iron encapsulation material, sample 9V1-NA. 

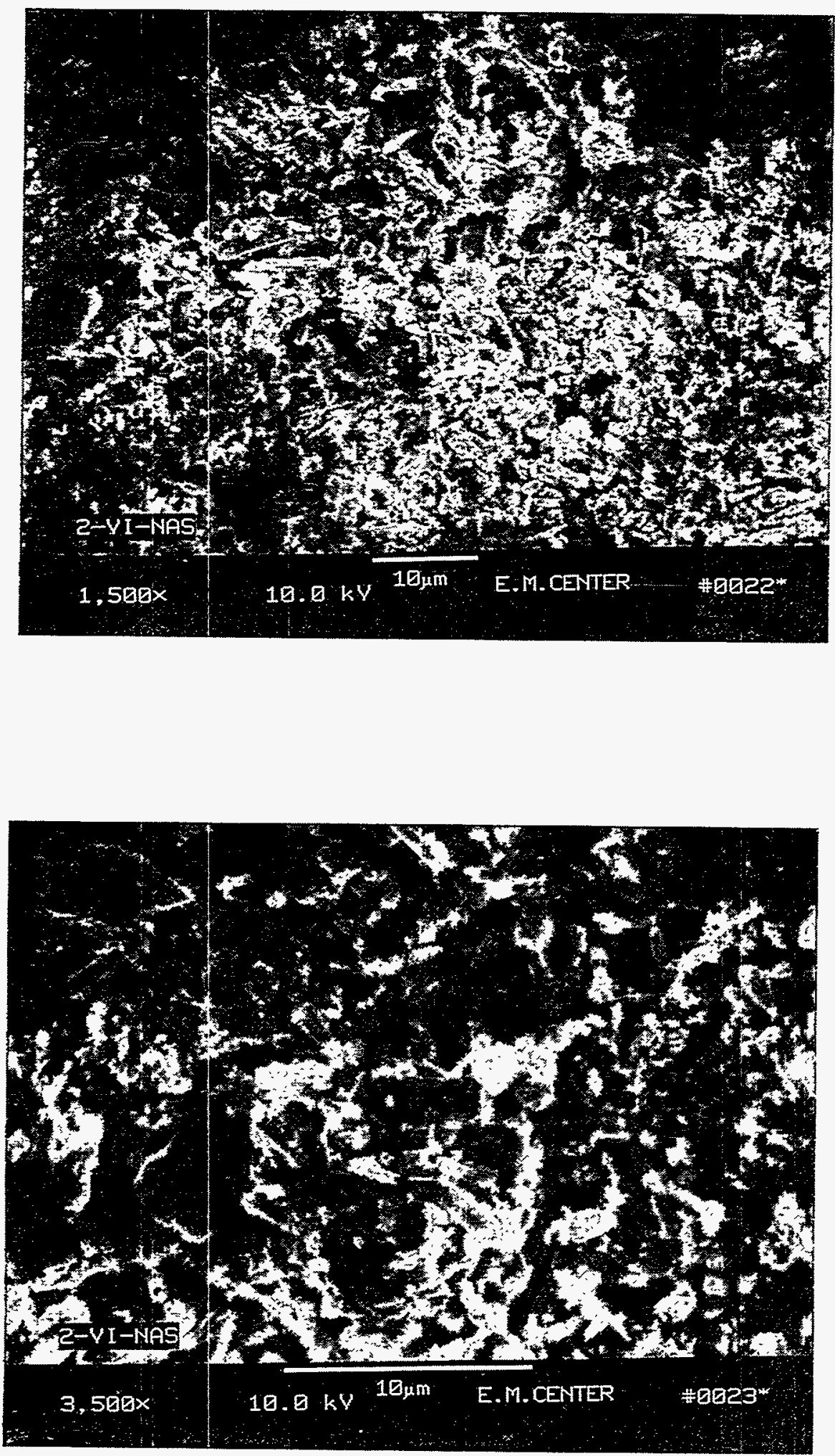

Figure 2. Photomicrographs of encapsulation material (soil mixture), sample 2V1-NAS. 


\subsubsection{Compressive Strength}

Compressive strength measurements showed that the strength of all samples exceeded the NRC minimum strength criteria (50 psi) for radioactive waste and that the waste isolation material was indifferent to the presence of metallic iron, cutting oil, or nitrate salts.

The measurements were carried out on materials identical to those described above. A set of compressive strength specimens were prepared, in triplicate, of several soil-waste isolation material compositions. The results of the compressive strength measurements are shown in Table 2.

A series of compressive strength specimens, containing metallic iron, potassium nitrate, or Texaco Regal Oil, were prepared to show the effect of nitrates on the waste encapsulation material performance. The results of compressive strength measurements are shown in Tables 3-5: All samples were prepared with the iron waste encapsulation material [ 3.76 to 1 by weight of ferrous sulphate, $\mathrm{FeSO}_{4} \cdot 7 \mathrm{H}_{2} \mathrm{O}$, and slaked lime, $\left.\mathrm{Ca}(\mathrm{OH})_{2}\right]$ and different amounts of soil versus possible SDA waste materials.

The data show that the compressive strength of all specimens exceeds the NRC 50 psi minimum compressive strength requirement for waste form materials. These data indicate that the iron oxide waste isolation material would prevent open space collapse if injected into a buried waste facility such as the SDA. The data in Tables 3-5 show that the presence of potassium nitrate, metallic iron, or oil has no detrimental effect on the compressive strength. Indeed, the data suggest that oil may actually increase the strength of the materials. Note that the data only apply to samples air dried to constant weight. Wetting caused the samples to disintegrate into a mud-like material in a manner identical to untreated INEL soil. The strength

Table 2. Relation between compressive strength and soil-waste isolation material mixtures (air dried to constant weight).

\begin{tabular}{|c|c|c|c|}
\hline $\begin{array}{c}\text { Soil }^{\mathrm{a}} \\
\text { (wt\%) }\end{array}$ & $\begin{array}{l}\text { Average compressive } \\
\text { strength } \\
\text { (psi) }\end{array}$ & $\begin{array}{l}\text { Standard } \\
\text { deviation }\end{array}$ & Trials \\
\hline 00 & 154 & 31 & 3 \\
\hline 25 & 176 & 53 & 3 \\
\hline 50 & 126 & 20 & 3 \\
\hline 75 & 164 & 21 & 2 \\
\hline
\end{tabular}


Table 3. Compressive strength of treated soils containing metallic iron (air dried to constant weight).

\begin{tabular}{cccc}
\hline $\begin{array}{c}\text { Ferrous } \\
\text { sulphate } \\
\text { (wt\%) }\end{array}$ & $\begin{array}{c}\text { Iron } \\
\text { (wt\%) }\end{array}$ & $\begin{array}{c}\text { Soil } \\
\text { (wt\%) }\end{array}$ & $\begin{array}{c}\text { Compressive } \\
\text { strength } \\
\text { (psi) }\end{array}$ \\
\hline 46.3 & 0 & 53.7 & $60^{\mathrm{a}}$ \\
46.3 & 7.3 & 46.1 & 119 \\
46.3 & 14.6 & 38.8 & 86 \\
46.3 & 29.1 & 24.3 & 106 \\
46.3 & 53.4 & 0 & 97
\end{tabular}

a. Average of two determinations that have $15.5 \%$ relative percent difference.

Table 4. Compressive strength of treated soils containing potassium nitrate (air dried to constant weight).

\begin{tabular}{cccc}
\hline $\begin{array}{c}\text { Ferrous } \\
\text { sulphate } \\
\text { (wt\%) }\end{array}$ & $\begin{array}{c}\text { Potassium } \\
\text { nitrate } \\
\text { (wt\%) }\end{array}$ & $\begin{array}{c}\text { Soil } \\
\text { (wt\%) }\end{array}$ & $\begin{array}{c}\text { Compressive } \\
\text { strength } \\
\text { (psi) }\end{array}$ \\
\hline 46.3 & 7.4 & 46.3 & 61.4 \\
46.3 & 29 & 24.7 & 53.8 \\
54.3 & 45.7 & 0 & 60.2 \\
89.5 & 6.5 & 4 & 62.4 \\
\hline
\end{tabular}

Table 5. Compressive strength of treated soils containing Texas Regal Oil (air dried to constant weight).

\begin{tabular}{cccc}
\hline $\begin{array}{c}\text { Ferrous } \\
\text { sulphate } \\
\text { (wt\%) }\end{array}$ & $\begin{array}{c}\text { Oil } \\
\text { (wt\%) }\end{array}$ & $\begin{array}{c}\text { Soil } \\
\text { (wt\%) }\end{array}$ & $\begin{array}{c}\text { Compressive } \\
\text { strength } \\
\text { (psi) }\end{array}$ \\
\hline 70.9 & 8.1 & 21 & 232 \\
78.7 & 21.3 & 0 & 262 \\
84.9 & 15.1 & 0 & 206 \\
\hline
\end{tabular}


of the waste isolation material is comparable to dried untreated INEL soil when prepared in a similar manner (see Table 2). The compressive strength of the $53.7 \mathrm{wt} \%$ soil, $46.3 \mathrm{wt} \%$ waste isolation material mixture in Table 3 has an anomalously low strength compared to similar materials listed in Table 2 ( 60 psi versus $164 \mathrm{psi}$ ). It is also anomalously low compared to other mixtures (which contain metallic iron) listed in Table 3 that were prepared at the same time. The reason for the low value is unknown, but may indicate that some excess moisture was present in the samples at the time the compressibility measurements were made.

In summary, the compressive strength and waste compatibility experiments indicate that waste materials such as metallic iron, nitrate salts, or oils have no appreciable effect on compressive strength, microstructure, or crystalline phases present. The presence of water affects the species of crystalline phases by controlling hydration reactions. Water also affects the oxidation-reduction reactions, probably by displacing air and thus retarding reaction with oxygen in air. Chemically uncombined water probably affects compressive strength; excess water causes disintegration of the soil-waste isolation material mixtures.

\subsection{TCLP Test Results}

The TCLP data show that, except for cadmium, the iron waste isolation material significantly removed the EPA hazardous metals from aqueous solution.

The results of the leach testing are shown in Table 6. The data clearly show that the iron oxide waste isolation material has a very significant effect on the aqueous concentration of most of the toxic metals tested. In most cases, the waste isolation material caused a decrease in hazardous metal concentration of two or more orders of magnitude compared to the reference soil containing added hazardous metals only. It should be noted that, in water, all samples disintegrated into a mud-like material indicating that the waste isolation material is not acting as a physical barrier. The decrease in concentration of heavy metals in solution is probable due to the chemical adsorption of the toxic metal ions onto the iron compounds in a manner similar to that reported by Morrison and Spangler. ${ }^{1}$ The data indicate that the waste isolation material effectively removes silver, arsenic, barium, and selenium from solution. The concentration of mercury in solution was reduced from 20.7 to $<2.5 \mathrm{ppm}$. This suggests that mercury may also be removed to concentrations less than the regulatory limit. However, the limit of detection, $2.5 \mathrm{ppm}$ at three times the standard deviation, is not sufficiently low to demonstrate this possibility. Lead was removed from solution to a much lesser extent, from 92.6 to 11.4 and $13.8 \mathrm{ppm}$. This is a reduction by a factor of about eight. The reduction in concentration of lead in solution is judged to be significant and may play an important role in lead remediation in field applications of the iron oxide waste isolation material. However, additional research to quantitatively establish the relation between lead adsorption and the iron oxide waste isolation material is needed before field application. The waste isolation materials appear to have no effect on the aqueous concentration of cadmium. Thus, the waste isolation material is obviously not suited for the remediation of cadmium. The chromium data are irrelevant because chromium was not dissolved by the leach treatment as indicated by the lack of chromium in the leachate taken from the reference soil containing the hazardous metals only. 
Table 6. TCLP leach testing results.

Concentration of hazardous element

(ppm)

\begin{tabular}{|c|c|c|c|c|c|c|c|c|}
\hline Sample & $\mathrm{Ag}$ & As & $\mathrm{Ba}$ & $\mathrm{Cd}$ & $\mathrm{Cr}$ & $\mathrm{Hg}$ & $\mathrm{Pb}$ & $\mathrm{Se}$ \\
\hline Regulatory limit ${ }^{\mathrm{a}}$ & 5.0 & 5.0 & 100 & 1.0 & 5.0 & 0.2 & 5.0 & 1.0 \\
\hline INEL soil & $<0.3$ & $<0.7$ & 0.14 & $<0.05$ & $<0.3$ & $<2.5$ & $<0.4$ & $<1.4$ \\
\hline Soil with hazardous metals & 40.8 & 389 & 368 & 368 & $<0.3$ & 20.7 & 92.6 & 62.8 \\
\hline $\begin{array}{l}\text { Soil and hazardous metals } \\
\text { with } 37 \text { wt\% isolation } \\
\text { material }\end{array}$ & $<0.3$ & $<0.7$ & $<0.07$ & 147 & $<0.3$ & $<2.5$ & 11.4 & $<1.4$ \\
\hline $\begin{array}{l}\text { Soil and hazardous metals } \\
\text { with } 62 \text { wt } \% \text { isolation } \\
\text { material }\end{array}$ & $<0.3$ & $<0.7$ & $<0.07$ & 418 & $<0.3$ & $<2.5$ & 13.8 & $<1.4$ \\
\hline
\end{tabular}

Concentration values shown with < symbol are values for the detection limit for that element that is defined as three times the standard deviation

a. 45 FR 33119, May 19, 1980, as amended at 55 FR 22684, June 1, 1990.

\subsection{Results of the Hydraulic Conductivity Measurements}

The hydraulic conductivity of soils treated with the iron waste encapsulation materials is about $10^{-6} \mathrm{~cm} / \mathrm{sec}$ and is virtually identical to similar measurements of untreated soil.

Hydraulic conductivity ( $k$ ) was estimated at various times from the beginning of the test until steady state was reached (i.e., dk/dt @ 0). Plots of hydraulic conductivity versus time for each specimen (see Figure 3) show that hydraulic conductivity tends to decrease with time due, in part, to differential consolidation of the specimens caused by seepage pressures induced by the hydraulic gradient. Higher effective stress at the top of the specimens causes constriction of flow with time and, as a result, a decrease in $\mathbf{k}$. All of the tests except one were continued for 300 hours to achieve steady state $k$. Specimen $2 b$ reached steady state $k$ more quickly than the other specimens due to its relatively high hydraulic conductivity. In terms of total effluent volume, the second largest amount of water was permeated through specimen $2 b$ even though its test duration was the shortest of all tests. The specimens permeated with the least total volume of water were the specimens with the lowest hydraulic conductivity (mixtures 1 and 3).

The steady state hydraulic conductivity values for each specimen are summarized in Table 7. The soil mixtures ( 1 and 3 ) performed two to five times better (i.e., lower $k$ ) than the soil/additive mixtures (2 and 4). Generally, no significant differences in $\mathrm{k}$ were observed between wet and dried specimens. The only exception is the dried soil/additive specimen $2 \mathrm{~b}$ which has a hydraulic conductivity more than five times larger than all of the other specimens including its replicated specimen 2a. Because this specimen was dried before testing, the atypical result could be due to the presence of more extensive desiccation cracks that provided preferential flow paths for the permeant fluid. 


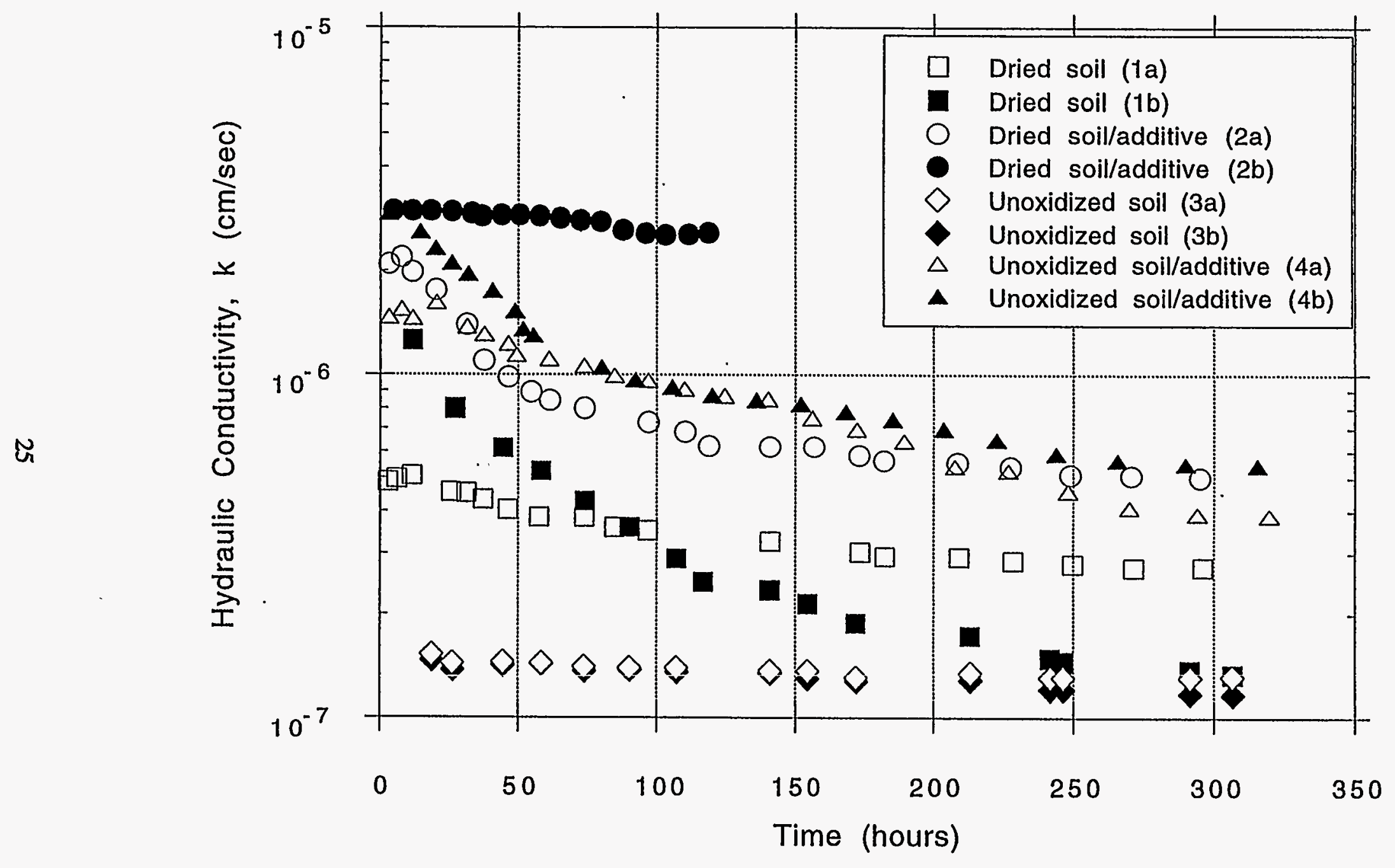

Figure 3. Hydraulic conductivity versus time for each test specimen. 
Table 7. Hydraulic conductivity results-final hydraulic conductivity and total effluent during test.

\begin{tabular}{cllc}
\hline Specimen & \multicolumn{1}{c}{ Description } & $\begin{array}{c}\text { Conductivity } \mathbf{k} \\
(\mathrm{cm} / \mathrm{sec})\end{array}$ & $\begin{array}{c}\text { Volume, } \\
\text { effluent } \\
\left(\mathrm{cm}^{3}\right)\end{array}$ \\
\hline 1a & Dried soil & $2.74 \times 10^{-7}$ & 687 \\
$1 \mathrm{~b}$ & Dried soil & $1.34 \times 10^{-7}$ & 685 \\
$2 \mathrm{a}$ & Dried soil/additive & $5.03 \times 10^{-7}$ & 1417 \\
2b & Dried soil/additive & $2.59 \times 10^{-6}$ & 1935 \\
3a & Wet soil & $1.32 \times 10^{-7}$ & 394 \\
3b & Wet soil & $1.17 \times 10^{-7}$ & 326 \\
4a & Wet soil/additive & $3.89 \times 10^{-7}$ & 1780 \\
$4 \mathrm{~b}$ & Wet soil/additive & $5.45 \times 10^{-7}$ & 2170 \\
\hline
\end{tabular}

Effluent from the soil/additive mixtures ( 2 and 4 ) had a distinct rust color, presumably due to dissolution of a chemical (e.g., iron) from the specimens into the pore fluid during permeation. The rust color was much darker in the wet specimens (4a and $4 b$ ), which also had a higher initial water content. This is consistent with the presence of iron sulphate compounds identified by the XRD analysis. Effluent from soil mixtures without the additive was clear.

\subsection{Field Application Parameters}

The method of application of the reagents to buried waste sites has not been developed at this time, although it is assumed that some form of jet grouting ${ }^{7}$ will be used. The application method will be required to be compatible with certain properties of the reagents. These properties are discussed in this section.

The results of the ferrous sulphate-slaked lime titration experiments are shown in Figures 4 and 5 and indicate that the ratio of ferrous sulphate to slaked lime needed to prepare the waste isolation material is stoichiometric for each reagent in its present form. The required ratio by weight of ferrous sulphate to slaked lime is 3.76 to 1 . This ratio will need to be verified for the actual lot of reagents used in the field application.

Most of the experiments were carried out by adding waste to ferrous sulphate-calcium hydroxide mixtures. This procedure always generated heat and produced a dark green viscous gel regardless of the presence of soil or waste materials. The dark green color probable indicates the presence of green rust $\left(\mathrm{Fe}_{2} \mathrm{O}_{3} \bullet \mathrm{H}_{2} \mathrm{O}\right)$, based on the XRD results, together with ferrous iron. The $\mathrm{pH}$ of the solutions were usually near neutral, 6.5-7.5, in contrast with SDA soil pH of about 8.0-8.3, the agriculture grade ferrous sulphate heptahydrate $\mathrm{pH}$ of 3.1, and slaked lime $\mathrm{pH}$ of 12 . 


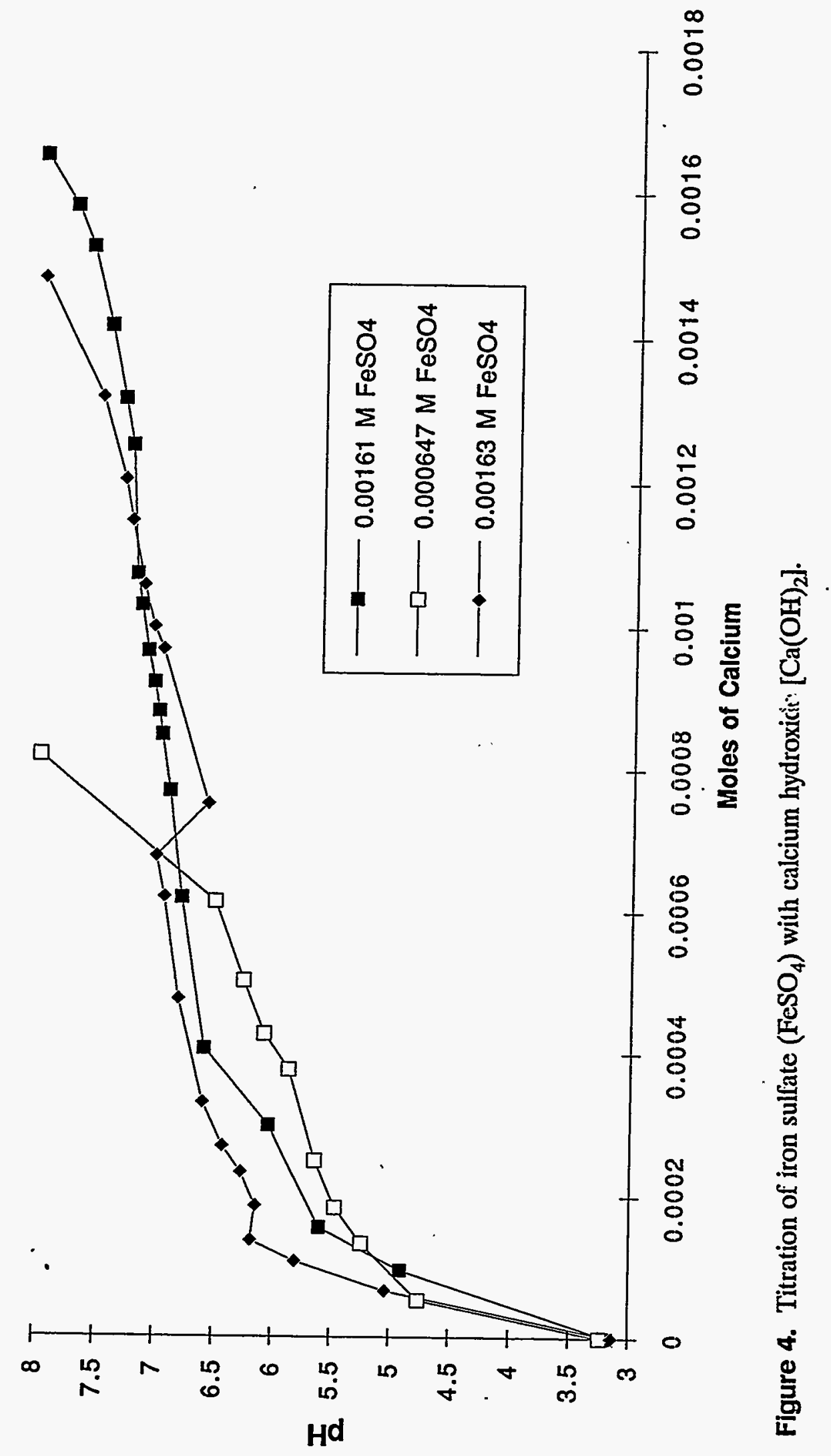




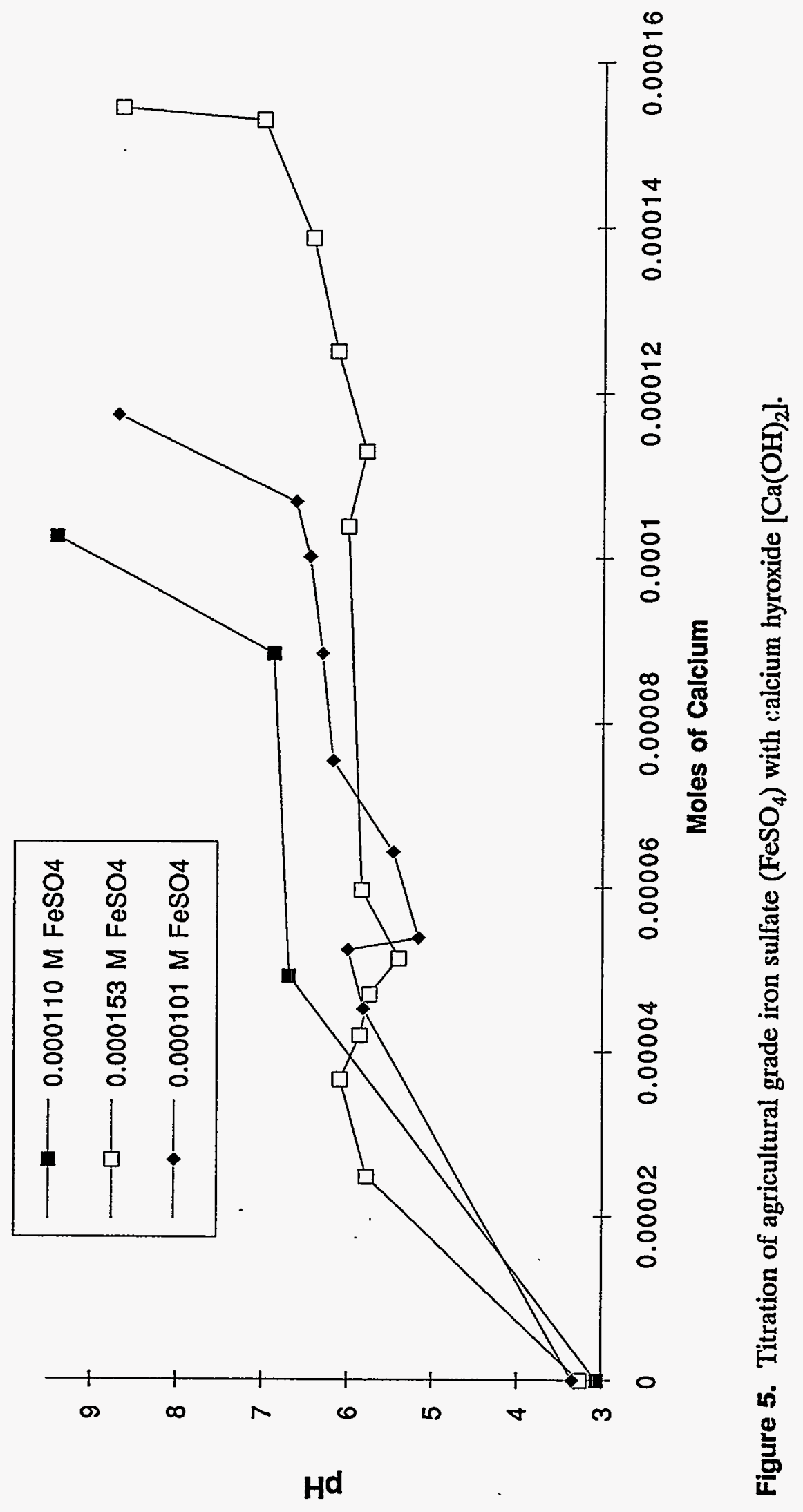


The reaction initiation time was examined by measuring the solution temperatures as a function of time, both at room temperature and with all reagents cooled to $0^{\circ} \mathrm{C}$. The results are shown in Figures 6 and 7 and indicate that the reaction was initiated within one or two minutes after mixing, starting at both room temperature and $0^{\circ} \mathrm{C}$. However, the XRD results indicate that the reactions continued for at least 10 days or more after mixing. The rapid initiation of reaction suggests that the two reagents not be mixed prior to field application, but rather be mixed during the field application process, perhaps by simultaneous injection.

Wet mixtures of the iron waste isolation reagents produced a firn, coherent, yellow-orange, somewhat porous material when air or oven dried. The result when nixed with soil was similar, but appeared to be somewhat less brittle. A decrease in volume always occurred, depending on the amount of water used to prepare the initial slurries. Direct measurement of the wet and dry volumes of the compressive strength specimens indicates that volume change due to dehydration can range from 15 to 35 vol\%, often accompanied by desiccation cracking.

Measurements of viscosity as a function of water content for each reagent were made for general information and are shown in Figures 8 and 9. Slaked lime is virtually insoluble in water, but has a very small grain size and remained in suspension with occasional stirring. Less stirring is required as the amount of slaked lime is increased and the mixture becomes very viscous. The ease of maintaining a suspension means that high concentration of slaked lime in slurries can be pumped for field application. The iron sulphate solutions behave somewhat differently. A saturated ferrous sulphate solution at room temperature contains $60 \mathrm{wt} \%$ ferrous sulphate heptahydrate. The solid ferrous sulphate in contact with solution did not remain in suspension, but immediately settled to the bottom of the container. Field application will be limited to use of the saturate solution unless the ferrous sulphate-water mixture is continually agitated as with a concrete mixer. The only slurries observed to developed "free water" upon standing contained more than 50 wt\% water.

Final note is the observation that the reagents react and set up into a hard coherent mass in the dry state, (i.e., without added water). Time required for the dry reaction in laboratory beakers was about three weeks. The dry reaction was not investigated further. This observation indicates that water is only required in order to manipulate the reagents and is not required for the reaction to proceed.

\subsection{CERCLA Criteria}

The data collected from the laboratory test meet the Compressive Environmental Response, Compensation, and Liability Act (CERCLA) criteria in some of the ways discussed below.

- The protection of human health and the environment is accomplished by the iron waste encapsulation materials because the data show that the encapsulation materials isolate waste from the environment and remove all the EPA hazardous metals from aqueous solution except for cadmium. 


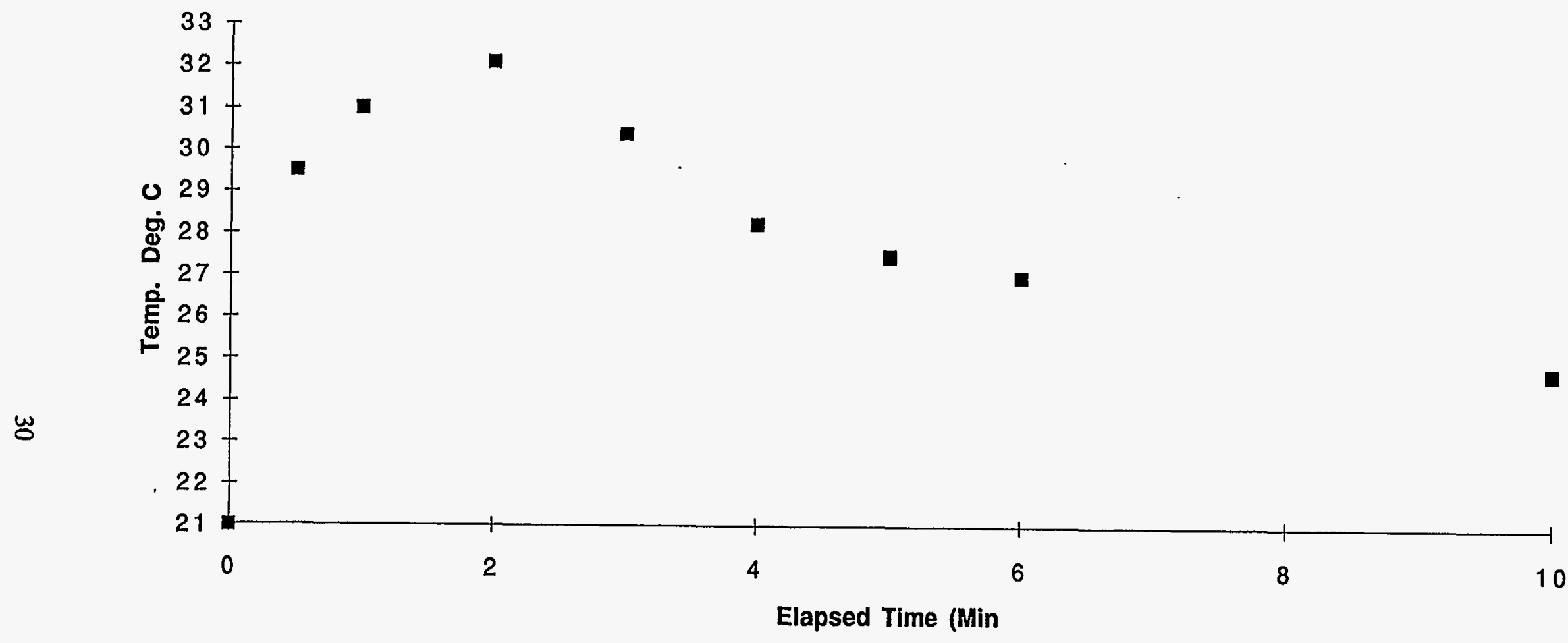

Flgure 6. Reaction of iron sulfate $\left(\mathrm{FeSO}_{4}\right)$, calcium hydroxide $\left[\mathrm{Ca}(\mathrm{OH})_{2}\right]$, and soil at room temperature. 


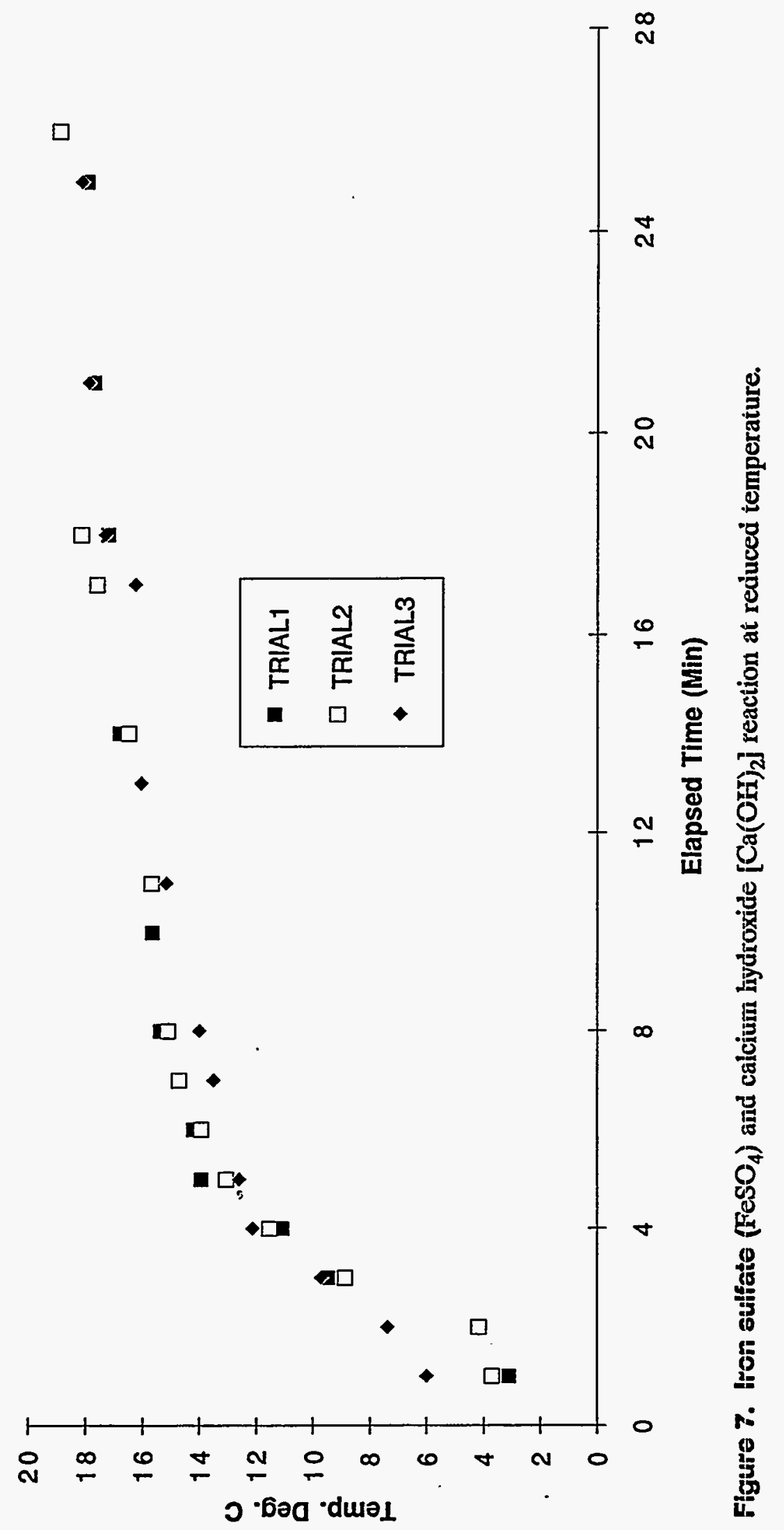




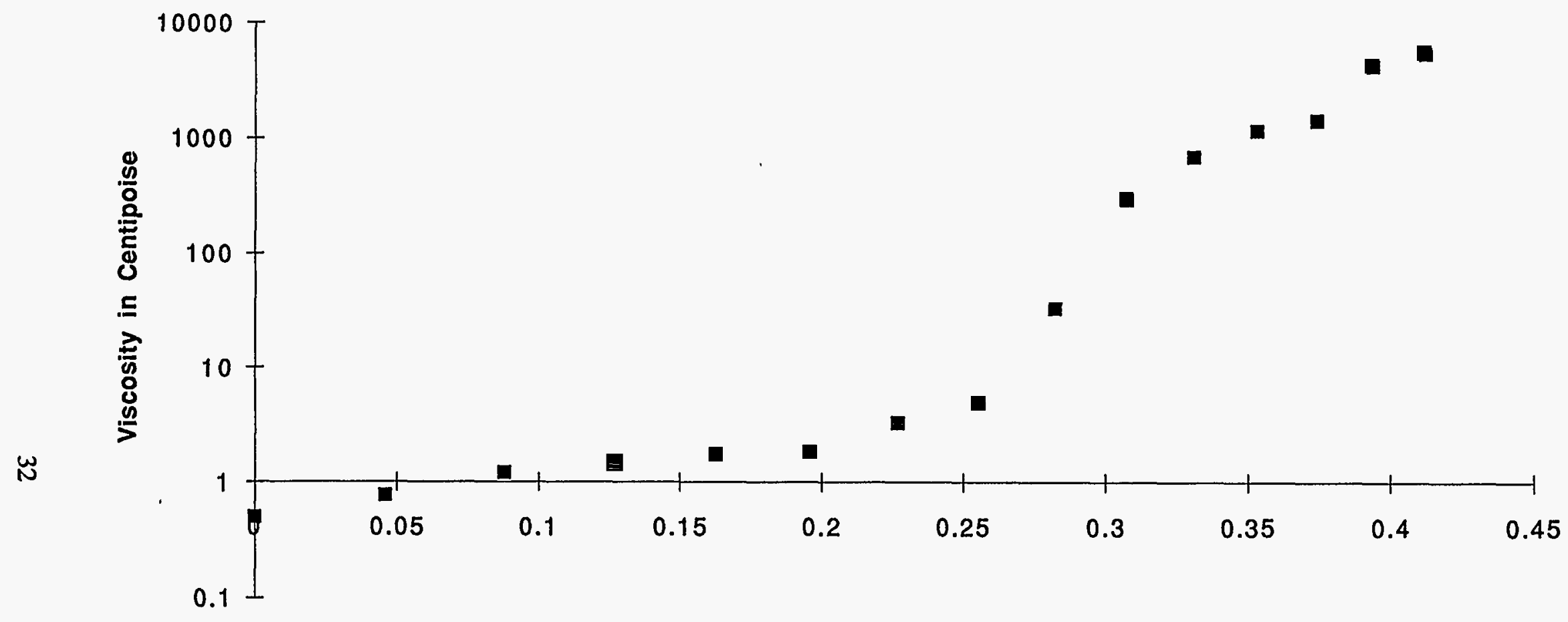

Wt\% Lime Suspended

Figure 8. Calcium hydroxide (agricultural lime) $\left[\mathrm{Ca}(\mathrm{OH})_{2}\right]$ slurry viscosity. 


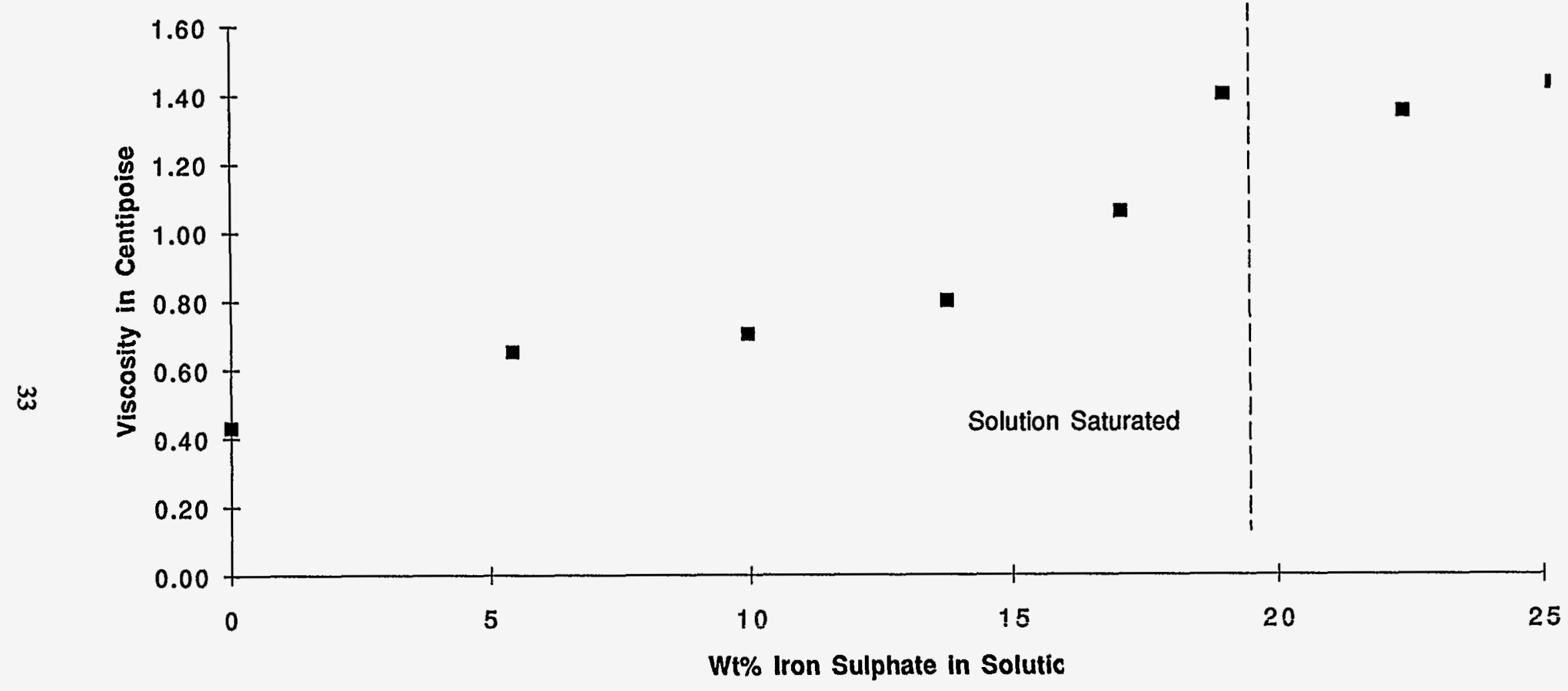

Figure 9. Agricultural grade iron sulfate $\left(\mathrm{FeSO}_{4}\right)$ solution viscosity. 
- Long-term effectiveness and permance and reduction of toxic mobility are optimum for the iron waste form because the materials are in virtual thermodynamic equilibrium with their environment and will only become more stable with time. This means that the waste form will be effective for geologic time periods.

- Short-term effectiveness is judged to be excellent based on the data obtained in this study. The data indicate that the waste form has sufficient strength to prevent collapse of buried waste sites and effectively removes hazardous metals from aqueous solution.

- Cost of application of the iron waste encapsulation materials has not been analyzed in detail because of insufficient funds. However, the cost is expected to be comparable to Portland cement grout and far less expensive than ex situ treatments.

- The state and community acceptance is excellent because the waste encapsulation materials are identical to natural rocks in the environment. 


\section{OUTPUT/PRODUCTS}

During the laboratory studies, less than $100 \mathrm{lb}$ of test materials were generated. The samples used for the hydraulic conductivity measurements made up about $80 \mathrm{lb}$ of the total waste and were disposed of at the Colorado State University (CSU) by CSU personnel. The remainder of the wastes was handled and disposed of according to current INEL practices and state and federal regulations. Less than 5 grams of materials used during TCLP testing was considered hazardous. The waste form itself was nonhazardous and was disposed of in a sanitary landfill.

Waste management practices are described in the Safety Manual and the "Laboratory" section of the Standard Practices Manual. Subsections of laboratory practices that apply to this study include "Nonradioactive Chemical Waste Disposal," "Chemical Lab Inventory," "Chemical Spill Control," and "Handling and Storage of Hazardous Waste in Satellite Accumulation Areas." Residuals management was conducted in accordance with NEPA document RWMC-93-019 (Appendix A). 


\section{PROBLEMS AND ISSUES FROM THE TESTING}

No problems and issues were identified with the testing, probably because this was a laboratory study. 


\section{FULL-SCALE IMPLEMENTATION}

The data and conclusions reported here are the result of laboratory-scale testing and, therefore, field tests and demonstrations must be carried out before full-scale implementation can be undertaken. The results to date indicate that the iron waste encapsulation materials are promising waste isolation and encapsulation materials. Attention neecls to be directed to the field-scale method(s) of application of the materials to the waste site before full-scale implementation can be contemplated. 


\section{CONCLUSIONS AND RECOMMENDATIONS}

The qualitative and quantitative data presented in Section 7 indicate that the iron waste isolation materials tested are appropriate choices for the intended purpose; namely, a material that when mixed with INEL soil (a) has hydraulic conductivity values less than $10^{-6} \mathrm{~cm} / \mathrm{sec}$, (b) has compressive strength sufficient to prevent collapse of the void space in waste (i.e., greater than the NRC 50 psi minimum), (c) removes hazardous metals, with the exception of cadmium, from solution by adsorption or other mechanism, and (d) appears to be chemically and physically inert with respect to the bulk of the waste materials likely to be found at the SDA.

Based on these conclusions, it would appear that tests are in order to determine the performance of the iron waste isolation materials under field conditions and for extended time periods (e.g., five years). Field application procedures need to be developed.

The amount of water should be minimized during field application. The experiments carried out in this study required that water be present in excess. This was done because the samples had to be manipulated in the wet state. The data indicate that excess water detrimentally affects porosity, cracking, shrinkage, hydraulic conductivity, and compressive strength of the waste isolation material. Attention should be directed toward developing methods for injection of the reagents in a dry or nearly dry state.

The ideal application system would use separate high-density, air-suspended, injection streams for each dry reagent. An acceptable, but less ideal, application system would use separate injection streams for each reagent, one with high density slaked lime slurry and the other solid ferrous sulphate-water mixture with the ferrous sulphate maintained in suspension by agitation. 


\section{REFERENCES}

1. S. J. Morrison and R. R. Spangler, "Chemical Barriers for Controlling Groundwater Contamination" Environmental Progress, 12, 3, 1993, pp. 175-181.

2. U.S. Environmental Protection Agency, Handbook on In Situ Treatment of Hazardous Waste-Contaminated Soils, PA/540/2-90/001, Risk Reduction Engineering Laboratory, Office of Research and Development, Cincinnati, Ohio, 1990.

3. G. G. Loomis and J. O. Low, J. O., Annual Technology Assessment and Progress Report for the Buried Transuranic Waste Studies Program at the INEL (1987), EGG-2525, 1988.

4. G. G. Loomis and J. O. Low, "In-Situ Grouting for Improved Confinement of Buried TRU Waste at the INEL," Proceedings from SPECTRUM '88, Pasco, Washington, September 11-15, 1988.

5. B. P. Spalding et al., "Grouting As a Remedial Technique for Problem Shallow Land Burial Trenches of Low-Level Radioactive Solid Wastes," Journal of Environmental Quality, Oak Ridge National Laboratory sponsored by Office of Defense and By-Product Management, 1983.

6. Code of Federal Regulations, 40 CFR 268, "Identification and Listing of Hazardous Waste," App. 1, U.S. Environmental Protection Agency, pp. 724-738.

7. G. G. Loomis and D. N. Thompson, Innovative Grout/Retrieval Demonstration Final Report, LITCO-94/001, 1994.

8. R. M. Garrels and C. L. Christ, Solutions, Minerals, and Equilibria, Freemon, Cooper \& Co., San Francisco, California, 1965.

9. J. A. Tullis, S. T. Marts, M. C. Pfeifer, and J. B. Sisson, Corrosive Properties of Backfill Soils at the Radioactive Waste Management Complex, Idaho National Engineering Laboratory, EGG-GEO-10382, EG\&G Idaho, Inc., 1993.

10. Jae-Ho Lee, G. P. Martins, and J. R. Weidner, Characterization Studies on:

(a) Contaminated Batch of Rocky Flats Soil and (b) Uncontaminated Batch of INEL Soil, EGG-WTD-9794, EG\&G Idaho, Inc., Idaho Falls, Idaho, 1991.

11. A. J. Sondrup, W. C. Downs, J. R. Weidner, and T. G. Kaser, Vertical Air Permeability in the Unsaturated Zone at the Radioactive Waste Management Complex, Engineering Design File ER-116, EG\&G Idaho, Inc., Idaho Falls, Idaho, 1993.

12. D. A. Arrenholtz and J. L. Knight, A Brief Analysis and Description of Transuranic Wastes in the Subsurface Disposal Area of the Radioactive Waste Management Complex at the INEL, EGG-WTD-9438, Rev. 1, EG\&G Idaho Inc., Idaho Falls, Idaho, 1991. 
13. S. O. Bates, Definition and Composition of Standard Waste Streams for Evaluation of Buried Waste Integrated Demonstration Treatment Technologies, EGG-WTD-10660, EG\&G Idaho, Inc., Idaho Falls, Idaho, 1993.

14. M. J Vigil, Subsurface Disposal Area (SDA) Waste Identification (1952-1970) Emphasis, EGG-WM-8727, Rev.1, EG\&G Idaho Inc., Idaho Falls, Idaho, 1989.

15. K. J. Liekhaus, Nonradioactive Inventory in Pit 9 at the RWMC, EDF-ERP-BWP-65, Rev. 2, EG\&G Idaho, Inc., Idaho Falls, Idaho, 1991.

16. J. F. Kaminsky, In Situ Characterization of Unsaturated Hydraulic Properties of Surficial Sediments Adjacent to the Radioactive Waste Management Complex, Idaho National Engineering Laboratory, master's thesis at Idaho State University, 1991.

17. J. R. Weidner, In Situ Encapsulation Bench Scale Demonstration Test Plan (for TTP-ID 142012), EGG-WTD-11410, EG\&G Idaho, Inc., Idaho Falls, Idaho, August 1994.

18. L. G. Olsen and D. J. Jeppesen, Soils of the Idaho National Engineering Laboratory, draft, EGG-CEMA-10641, EG\&G Idaho, Inc., Idaho Falls, Idaho, 1993.

19. J. W. Wey and E. B. McNew, Elemental Analysis of INEL Soils by X-Ray Fluorescence Spectrometry, Inductively Coupled Plasma Spectroscopy and Combustion Analysis in Support of OU 12-06 Radionuclide Contaminated Soils Remedial Investigation/Feasibility Study, ER-94-033, EG\&G Idaho, Inc., Idaho Falls, Idaho, 1994.

20. J. R. Weidner, INEL Support to the Plutonium in Soil Integrated Demonstration Nevada, Interim Report, EGG-WTD-10386, EG\&G Idaho, Inc., Idaho Falls, Idaho, 1992.

21. American Society of Testing Materials, C-3986, "Compressive strength of Concrete Specimens," 1986.

22. K. Norrish and B. W. Chappell, "X-ray Fluorescence Spectrometry," Chapter 5, Physical Methods in Determinative Mineralogy, J. Zussman (ed.), Academic Press Inc., London, 1977. 


\section{Appendix A}

\section{X-ray Powder Diffraction and Scanning Electron Microscope Procedures}


. 


\section{Appendix A}

\section{X-ray Powder Diffraction and Scanning Electron Microscope Procedures}

X-ray powder diffraction is a method used to identify the mineral and other crystalline species present in a soil sample. The procedure used in this study is the standard method used for soil samples and is described by L. D. Whittig and W. R. Allardice, "X-ray Diffraction Techniques," Chapter 12, Methods of Soil Analysis, Part 1, Physical and Mineralogical Methods Agronomy Monograph No. 9 (2nd Edition) A. Klute (ed.), American Society of Agronomy, 1986, pp. 331-376.

Both wet and dry samples were analyzed using the XRD. All samples were powders and needed no sample additional preparation. The dry samples were loaded into standard samples . holders. The wet samples were smeared into the sample holders and run "as is" with less than one minute exposure time to air.

A Seimens D5000 XRD instrument running at $50 \mathrm{kV}$ and $30 \mathrm{~mA}$ was used for all measurements except the slaked lime sample which was analyzed at the IRC. XRD scans were made from 5 to 70 degrees two theta. All samples were run for 57 minutes.

The XRD apparatus is equipped so that the diffraction data are stored and processed electronically. Unknown phases within each sample are identified by electronically comparing the measure data with the properties of standard, known, crystalline materials compiled by the International Centre for Diffraction Data (ICDD, 1992 edition). Ferrous sulphate starting material and a soil sample were also measured and used for reference. The XRD and SEM data were taken by Professor Charles Knowles at the University of Idaho, Department of Geology and Geological Engineering, August, 1994. The calcium hydroxide starting material was measured in the Idaho Research Center x-ray diffraction laboratory using similar equipment. Phase identification used both the computer-controlled comparison and direct observation by Knowles and the author, Jerry Weidner. The final phase identification and check was done by the author.

Photomicrographs were taken of consolidated fragments from the dry samples using an Amry 1830 instrument at $10 \mathrm{kV}$ and scanned at 3500 and $1500 \mathrm{X}$. The samples were mounted on an aluminum stub and coated with Au-Pd alloy for good conduction and secondary electron yield. 


\section{Appendix B}

\section{X-ray Fluorescence Analysis Procedures}

B-1 
- 


\section{Appendix B}

\section{X-ray Fluorescence Analysis Procedures}

$\mathrm{X}$-ray fluorescence spectrometry is a standard analytical technique and is the method that was used to carry out a qualitative determination of the chemical composition of the waste encapsulation reagents used for testing. A procedure for soil and similar materials is described by K. Norrish and B. W. Chappell, "X-ray Fluorescence Spectrometry," Chapter 5, Physical Methods in Determinative Mineralogy, J. Zussman (ed.), London: Academic Press, Inc., 1977.

The ferrous sulphate heptahydrate $\left(\mathrm{FeSO}_{4} \cdot 7 \mathrm{H}_{2} \mathrm{O}\right)$ and calcium hydroxide $\mathrm{Ca}(\mathrm{OH})_{2}$ starting materials were analyzed as received. The samples were placed in polyethylene cups with a $3.6 \mu \mathrm{m}$ thick mylar bottom (transparent to $\mathrm{x}$-rays). The samples were analyzed using a KEVEX Model $770 \mathrm{x}$-ray fluorescence spectrometer. The conditions used to analyze the elements found in each sample are listed in Tables B-1 to B-3.

A qualitative estimate of the concentration of each trace and minor element found was obtained by comparing the raw counts for each impurity element to iron in the ferrous sulphate sample and calcium in the calcium hydroxide sample. 
Table B-1. XRF analysis conditions.

\begin{tabular}{lcccc}
\hline \multicolumn{1}{c}{ Element } & $\begin{array}{c}\text { Secondary } \\
\text { target }\end{array}$ & $\mathrm{kV}$ & $\mathrm{mA}$ & $\begin{array}{c}\text { Irradiation } \\
\text { time } \\
(\mathrm{sec})\end{array}$ \\
\hline $\mathrm{Si}, \mathrm{P}, \mathrm{S}$ & - & 5 & 0.15 & 180 \\
$\mathrm{Ca}, \mathrm{Cr}, \mathrm{Mn}, \mathrm{Fe}, \mathrm{Cu}, \mathrm{Zn}$ & $\mathrm{Ge}$ & 15 & 1.00 & 1,200 \\
$\mathrm{Sr}, \mathrm{Y}, \mathrm{Zr}$ & $\mathrm{Ag}$ & 40 & 0.62 & 1,200 \\
\hline
\end{tabular}

Table B-2. XRF analysis of $\mathrm{FeSO}_{4}$ sample.

\begin{tabular}{lc}
\hline Element & $\begin{array}{c}\text { Concentration } \\
(\approx \mathrm{ppm})\end{array}$ \\
\hline $\mathrm{P}$ & 400 \\
$\mathrm{Ca}$ & 580 \\
$\mathrm{Cr}$ & 90 \\
$\mathrm{Mn}$ & 530 \\
$\mathrm{Zn}$ & 210 \\
\hline
\end{tabular}

Table B-3. XRF analysis of $\mathrm{Ca}(\mathrm{OH})_{2}$ sample.

\begin{tabular}{lc}
\hline Element & $\begin{array}{c}\text { Concentration } \\
(\approx \mathrm{ppm})\end{array}$ \\
\hline $\mathrm{Si}$ & 640 \\
$\mathrm{P}$ & 1,600 \\
$\mathrm{Mn}$ & 840 \\
$\mathrm{Fe}$ & 1,750 \\
$\mathrm{Cu}$ & 430 \\
$\mathrm{Zn}$ & 460 \\
$\mathrm{Sr}$ & 2,100 \\
$\mathrm{Y}$ & 2,100 \\
$\mathrm{Zr}$ & 3,000 \\
\hline
\end{tabular}




\section{Appendix C}

Permeability Measurement Procedure and Test Conditions 


\section{.}

, 


\section{Appendix C}

\section{Permeability Measurement Procedure and Test Conditions}

Flexible wall permeability tests were conducted to determine the hydraulic conductivity $(k)$ of each of the eight specimens listed in Table C-1 and were performed in general accordance with test method C of ASTM D5084-90, the standard test method for measuring $k$ of saturated porous materials using a flexible wall permeameter with a falling headwater/rising tailwater evaluation. However, in order to carry out the tests in a timely manner the procedure for this test program was (a) modified from the standard test method, namely, backpressuring was not used to saturate the specimens and (b) the applied hydraulic gradient of 25 was slightly larger than the recommended hydraulic gradient of 20 for specimens with hydraulic conductivities between $10^{-6}$ and $10^{-7} \mathrm{~cm} / \mathrm{sec}$.

Each specimen was extruded, placed into a triaxial permeability cell, and enclosed by a thin rubber membrane. The specimens are described in Table $\mathrm{C}-1$. Porous stones and filter paper also were placed on the top and bottom of the specimens to ensure free drainage and to prevent migration of soil particles into the apparatus. The cells were then filled with water and a cell pressure and back pressure of 15 and 5 psi, respectively, were applied to each specimen. These applied pressures would result in an average effective stress of $10 \mathrm{psi}$ when the specimens are saturated. The specimens were allowed to consolidate for 24 hours under these applied cell and back pressures. At this point, ASTM D5084-90 requires backpressuring in order to attain saturation before permeation. However, this stage usually takes about 10 days per specimen to complete and typically does not represent the unsaturated conditions that exist in many field applications. Therefore, backpressure saturation was not implemented in this test program.

After the consolidation stage, a hydraulic gradient of 25 was applied by increasing the pressure on the bottom of the specimen from 5 to $9 \mathrm{psi}$. This applied gradient was slightly greater than the value of 20 recommended by ASTM D5084-90 for specimens with a hydraulic conductivity between $10^{-6}$ and $10^{-7} \mathrm{~cm} / \mathrm{sec}$. However, because the hydraulic conductivity of the specimens was not known a priori, it was difficult to apply the recommended gradient. The difference between applied and recommended gradients is believed to have no significant effect on the test results.

Application of the hydraulic gradient caused the effective stress distribution across the specimens to change from a constant $10 \mathrm{psi}$ to a linear distribution starting at $10 \mathrm{psi}$ at the top and decreasing to $6 \mathrm{psi}$ at the bottom (assuming saturated conditions). The stress conditions are summarized in Table C-2. Each specimen was permeated with distilled, de-ionized water and water levels in both the inflow and outflow accumulators were measured in order to compute hydraulic conductivity. Hydraulic conductivity values were computed using the falling headwater/rising tailwater equation [ASTM D5084-90, Section 9, Eq. (3)]:

$$
K=\frac{a_{\text {in }} a_{\text {out }}}{a_{\text {in }}+a_{\text {out }} A \Delta t} \times \operatorname{In}\left(h_{1} / h_{2}\right)
$$


where:

$\mathbf{k}=$ hydraulic conductivity $(\mathrm{cm} / \mathrm{sec})$

A $=$ cross-sectional area of the specimen $\left(\mathrm{cm}^{2}\right)$

$a_{\text {in }}=$ cross-sectional area of inflow accumulator $\left(\mathrm{cm}^{2}\right)$

$a_{\text {out }}=$ cross-sectional area of outflow accumulator $\left(\mathrm{cm}^{2}\right)$

$L=$ length of the specimen $(\mathrm{cm})$

$\Delta t=$ elapsed time $\left(=t_{2}-t_{1}\right)$

$h_{1}=$ head loss across the specimen at time $t_{1}(\mathrm{~cm})$

$\mathrm{h}_{2}=$ head loss across the specimen at time $t_{2}(\mathrm{~cm})$.

Each test was continued until $\mathrm{k}$ was virtually constant with respect to time. 
Table C-1. Description of test specimens.

\begin{tabular}{|c|c|c|c|c|}
\hline Mixture & Specimen & Description & $\begin{array}{l}\text { Length } \\
\text { (cm) }\end{array}$ & $\begin{array}{l}\text { Area } \\
\left(\mathrm{cm}^{2}\right)\end{array}$ \\
\hline \multirow[t]{2}{*}{1} & $1 \mathrm{a}$ & Dried soil & 11.08 & 74.40 \\
\hline & $1 \mathrm{~b}$ & & 11.35 & 76.51 \\
\hline \multirow[t]{2}{*}{2} & $2 a$ & Dried soil/additives & 11.24 & 71.03 \\
\hline & $2 b$ & & 11.31 & 76.51 \\
\hline \multirow[t]{2}{*}{3} & $3 a$ & Wet soil & 10.00 & 84.13 \\
\hline & $3 b$ & & 10.50 & 79.96 \\
\hline \multirow[t]{2}{*}{4} & $4 a$ & Wet soil/additives & 11.61 & 81.38 \\
\hline & $4 \mathrm{~b}$ & & 11.60 & 79.33 \\
\hline
\end{tabular}

Table C-2. Stress conditions for flexible wall permeability tests (ASTM D5084-90).

\begin{tabular}{lcc}
\multicolumn{1}{c}{ Parameter } & Value & $\begin{array}{c}\text { Recommended } \\
\text { value }\end{array}$ \\
\hline Hydraulic gradient (i) & 25 & 20 \\
Applied pressure, bottom (psi) & 9 & - \\
Applied pressure, top (psi) & 5 & - \\
Applied pressure, cell & 15 & - \\
Average effective stress (psi) & 8 & - \\
Effective stress, bottom (psi) & 6 & $>1$ \\
Effective stress, top (psi) & 10 & $>1$ \\
\hline
\end{tabular}

